\title{
Review \\ Physiological Effects of Bioactive Compounds Derived from Whole Grains on Cardiovascular and Metabolic Diseases
}

\author{
Sangwon Chung ${ }^{1} \mathbb{D}$, Jin-Taek Hwang ${ }^{1,2}$ and Soo-Hyun Park ${ }^{1, *}$ \\ 1 Personalized Diet Research Group, Food Functionality Research Division, Korea Food Research Institute, \\ Wanju-gun 55365, Korea; schung@kfri.re.kr (S.C.); jthwang@kfri.re.kr (J.-T.H.) \\ 2 Department of Food Biotechnology, University of Science and Technology, Daejeon 34113, Korea \\ * Correspondence: shpark0204@kfri.re.kr
}

Citation: Chung, S.; Hwang, J.-T.; Park, S.-H. Physiological Effects of Bioactive Compounds Derived from Whole Grains on Cardiovascular and Metabolic Diseases. Appl. Sci. 2022, 12, 658. https://doi.org/10.3390/ app12020658

Academic Editors: Anna Lante and Jae-Ho Park

Received: 7 December 2021

Accepted: 6 January 2022

Published: 10 January 2022

Publisher's Note: MDPI stays neutral with regard to jurisdictional claims in published maps and institutional affiliations.

Copyright: (c) 2022 by the authors. Licensee MDPI, Basel, Switzerland. This article is an open access article distributed under the terms and conditions of the Creative Commons Attribution (CC BY) license (https:// creativecommons.org/licenses/by/ $4.0 /)$.

\begin{abstract}
Cardiovascular diseases are a global health burden with an increasing prevalence. In addition, various metabolic diseases, such as obesity, diabetes, and hypertension are associated with a higher risk of cardiovascular diseases. Dietary strategies based on healthy foods have been suggested for the prevention or improvement of cardiovascular and metabolic diseases. Grains are the most widely consumed food worldwide, and the preventive effects of whole grains (e.g., oats, barley, and buckwheat) on metabolic diseases have been reported. The germ and bran of grains are rich in compounds, including phytochemicals, vitamins, minerals, and dietary fiber, and these compounds are effective in preventing and improving cardiovascular and metabolic diseases. Thus, this review describes the characteristics and functions of bioactive ingredients in whole grains, focusing on mechanisms by which polyphenols, antioxidants, and dietary fiber contribute to cardiovascular and metabolic diseases, based on preclinical and clinical studies. There is clear evidence for the broad preventive and therapeutic effects of whole grains, supporting the value of early dietary intervention.
\end{abstract}

Keywords: whole grain; bioactive compounds; cardiovascular disease; metabolic disease

\section{Introduction}

Human beings are constantly striving for the development of methods for the prevention and treatment of diseases. In the Global Burden of Disease (GBD) 2019 data, the prevalence of cardiovascular disease has approximately doubled over the past 30 years [1]. In addition, cardiovascular diseases are linked to risk factors for metabolic diseases, such as obesity and diabetes [2]. Therefore, lowering the prevalence of metabolic and cardiovascular diseases is considered one of the biggest challenges of today.

It is well known that increases in the prevalence of metabolic and cardiovascular diseases are closely related to lifestyle patterns, such as physical activity and dietary habits [3,4]. Therefore, unlike other diseases, substantial efforts to prevent metabolic and cardiovascular diseases have focused on lifestyle corrections prior to medical treatment. As part of this, food and food ingredients that help prevent metabolic and cardiovascular diseases are attracting attention. In particular, interest in plant-derived phytochemicals is growing $[5,6]$.

The most commonly consumed food in the world is grains (e.g., oats, barley, and buckwheat), which are a source of carbohydrates. In general, people around the world, on average, get almost $50 \%$ of their daily energy intake from carbohydrates [7-10]; accordingly, the impact of grain quality on health cannot be overlooked. Previously, many people preferred refined grains with a soft texture. However, interest in whole grains has increased continuously as various nutrients and active ingredients contained in whole grains have been revealed. More than $80 \%$ of whole grains consist of endosperm, and the hull contains germ and bran (Figure 1). Most of them consist of carbohydrates, but they also contain proteins, vitamins, and minerals. In particular, germ and bran contain dietary fiber, $\mathrm{B}$ vitamins, minerals, and various phytochemicals [11]. However, most of the germ and 
bran are removed through the milling process [12]. Many studies have shown that various nutrients and active ingredients in whole grains, especially in the germ or bran, are effective in improving chronic diseases, including metabolic and cardiovascular diseases [13-18]. Representatively, there are phenol- and dietary fiber-derived compounds. In addition, it contains various tocols, which are vitamin $\mathrm{E}$ with strong antioxidant activity. They are known to be involved in blood glucose and lipid metabolism, as well as having antioxidant and anti-inflammatory effects [19-22]. Due to the influence of these various bioactive compounds, it has been reported that whole grain consumption is the main factor affecting mortality due to cardiovascular disease [23]. Indeed, three servings of whole grains per day was associated with a reduced risk of mortality from cardiovascular diseases in a metaanalysis [24]. In another meta-analysis study with various cohorts, it was also reported that consuming three servings of whole grains reduced the relative risk of mortality from metabolic diseases and cancers, as well as cardiovascular disease prevalence [25]. However, the associations between various bioactive compounds in whole grains and risk factors for metabolic and cardiovascular diseases have rarely been reviewed.

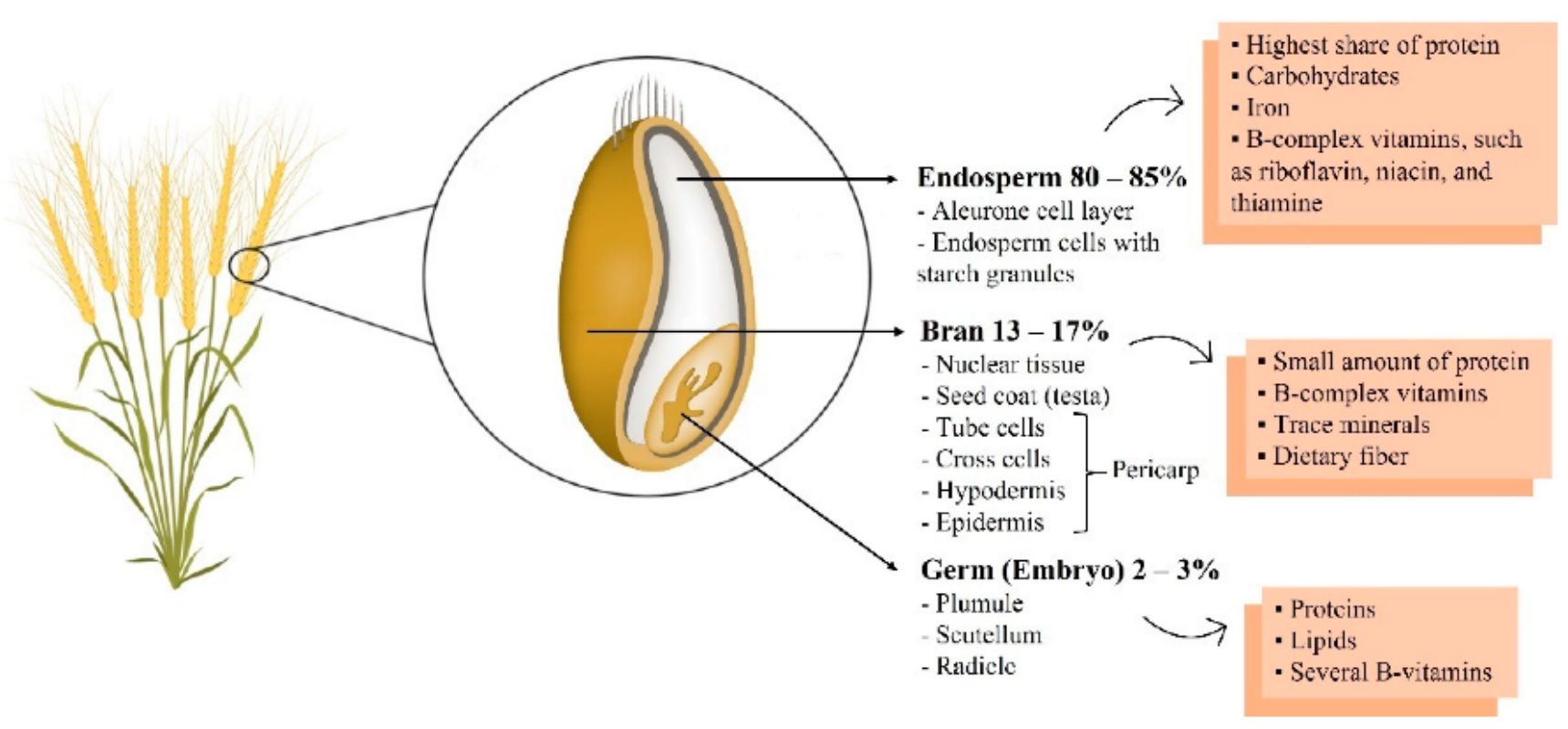

Figure 1. Whole grain wheat composition. Reproduced with permission from Sabença et al., Wheat/gluten-related disorders and gluten-free diet misconceptions: A review; published by Foods, 2021 [11].

Therefore, a literature review was performed to evaluate the characteristics and functions of active ingredients in whole grains and the effects of whole grain consumption on metabolic and cardiovascular diseases. In particular, we describe recent findings on phenol-, vitamin E-, and dietary fiber-derived bioactive compounds, which are representative bioactive compounds in the following four major groups (including eight compounds): whole grain-specific polyphenols, including alkylresorcinols (ARs), avenanthramides (Avns), ferulic acids (FA), and $\gamma$-oryzanol (OZ); flavonoids, including rutin; vitamin $\mathrm{E}$, including tocotrienol and $\alpha$-tocopherol; dietary fiber, including $\beta$-glucan (Figure 2 ). 
<smiles>CCCCCC/C=C\CCCCCCCc1cc(O)cc(O)c1</smiles>

(a)<smiles>COc1cc(/C=C/C(=O)O)ccc1O</smiles>

(c)

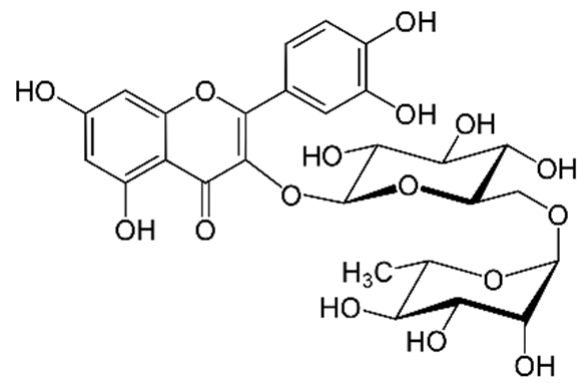

(e)<smiles>Cc1c(C)c2c(c(C)c1O)CC[C@@](C)(CCC[C@H](C)CCC[C@H](C)CCCC(C)C)O2</smiles>

(g)<smiles>[R]c1cc(C(=O)O)c(NC(=O)/C(C)=C/c2ccc(O)cc2)cc1[R][H]</smiles>

(b)<smiles>COc1ccc(/C=C/C(=O)O[C@H]2CC[C@]34C[C@]35CC[C@@]3(C)[C@H](CC[C@]24C)[C@@]5(C)CC[C@@H]3[C@@H](C)CCC=C(C)C)cc1O</smiles>

(d)<smiles>[R]c1c([R])c2c(c([R])c1O)CC[C@@](C)(CC/C=C(\C)CC/C=C(\C)CCC=C(C)C)O2</smiles>

(f)

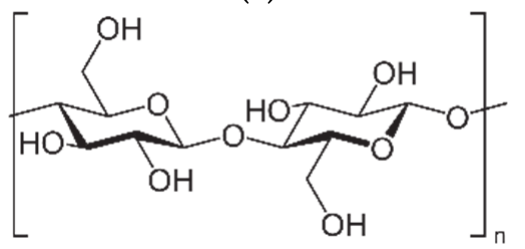

(h)

Figure 2. Main structure of whole grain-derived bioactive compounds (a) alkylresorcinol, (b) avenanthramide, (c) ferulic acid, (d) $\gamma$-oryzanol, (e) rutin, (f) tocotrienol, (g) $\alpha$-tocopherol, and (h) $\beta$-glucan.

\section{Associations of Whole Grain-Specific Polyphenols with Cardiovascular and Metabolic Diseases}

Polyphenols are phenolic compounds with one or more phenol units per molecule and are present in most plant materials, such as vegetables, fruits, and grains [26]. They effectively improve various metabolic and cardiovascular diseases due to their excellent antioxidant and anti-inflammatory effects $[27,28]$. Representative polyphenol compounds, present in whole grains, are alkylresorcinols (ARs), avenanthramides (Avns), ferulic acids (FA), and $\gamma$-oryzanol (OZ) [29-32].

\subsection{Alkylresorcinols (ARs)}

Alkylresorcinols are phenolic lipids, consisting of phenolic rings and long aliphatic hydrocarbon chains [29]. They are mainly present in the bran layer of whole grains and are widely used as biomarkers for the intake of whole grains.

It has been reported in many studies of glucose intolerance, especially in metabolic diseases. According to a prospective cohort study of old adults and pregnant women, blood 
AR concentrations and the frequency of whole grain intake were negatively correlated with the incidence of impaired glucose tolerance (IGT) and gestational diabetes mellitus (GDM) $[33,34]$. In addition, in a case-control study of patients with IGT and type 2 diabetes (T2D), higher levels of DHPPA [3-(3,5-dihydroxyphenyl)-1-propanoic acid], a metabolite of ARs, were correlated with a lower incidence of IGT and T2D [35]. Evidence for the contribution of ARs to glycemic control and the underlying mechanisms has been obtained by studies of mouse models of high-fat, high-sucrose diet (HFHS)-induced obesity and glucose intolerance. In this model, ARs alleviate glucose intolerance and insulin resistance by decreasing insulin and leptin secretion and increasing insulin-stimulated hepatic serine/threonine protein kinase B phosphorylation. In addition, cholesterol levels decreased via the upregulation of hepatic cholesterol synthetic genes, such as sterol regulatory element binding transcription factor 2 (Srebf2) and 3-hydroxy-3-methylglutaryl-CoA synthase 1 (Hmgcs1), as well as increasing fecal excretion of cholesterol [36]. As such, ARs showed an excellent effect in controlling blood glucose and lipids that directly or indirectly affect cardiovascular diseases. Therefore, these study results provide scientific evidences to support a human study that elevated blood DHPPA levels, induced by whole grain intake, lowered the prevalence of ischemic stroke [16].

\subsection{Avenanthramides (Avns)}

Avenanthramides are $N$-cinnamoyl derivatives of anthranilic acid, a group of phenolic alkaloids [30]. They exist in various plant materials, but they are widely known as phytochemicals in whole grain oats.

It has been reported to prevent vascular diseases in various preclinical studies. In $\mathrm{LDLr}^{-/-}$mice fed a high-fat diet (HFD), oat bran with Avns reduced total cholesterol (TC) and atheroma lesions in the aortic valve. These effects were more pronounced in the highAvns diet group than in the low-Avns diet group [17]. The mechanism, for the protective effects of Avns against vascular diseases, has been investigated using vascular endothelial and smooth muscle cells (SMCs). Avns inhibit the proliferation of SMCs by increasing the levels of nitric oxide (NO), cyclic guanosine monophosphate (cGMP), upregulating endothelial nitric oxide synthase (eNOS), and protein kinase B (Akt) in human umbilical vein endothelial cells (HUVECs), human aortic endothelial cells (HAECs), and SMCs [37,38]. Nie et al. [39] reported that Avns induce G1 phase arrest of SMC proliferation in rat embryonic aortic SMCs by suppressing the phosphorylation of retinoblastoma protein ( $\mathrm{pRb})$, involved in the cell cycle. The phosphorylation of $\mathrm{pRb}$ and cell cycle arrest are induced by the inhibition of cyclin D1 expression and upregulation of the p53-p21cip pathway. Since vascular inflammation is one of the factors that induces cardiovascular diseases, including atherosclerosis, its effects have also been explored in various in vitro models. In IL- $1 \beta$ or TNF- $\alpha$-stimulated endothelial cells or SMCs, the secretion of inflammatory mediators is increased by mitogen-activated protein kinase (MAPK) signaling, and cell migration and proliferation are increased by matrix metalloproteinase (MMP) activity. Avns decrease the secretion of pro-inflammatory cytokines and inhibit the migration and proliferation of SMCs by downregulating MAPK signaling and suppressing MMP protein expression and NF- $\kappa B$ activation [40-42].

\subsection{Ferulic Acid (FA) and $\gamma$-Oryzanol (OZ)}

Ferulic acid (4-hydroxy-3-methoxycinnamic acid) is a derivative of hydroxycinnamic acid, a type of phenolic acid [31]. $\gamma$-oryzanol is a ferulic acid mixture in which triterpenoids are bound to esterified ferulic acid [43]. Both compounds are representative bioactive substances of whole-grain rice bran [31,32]. FA and OZ are effective in improving cardiovascular and metabolic diseases.

The beneficial effects of FA and OZ on cardiovascular disease have been confirmed in animal models fed a HFD or high-fat, high-fructose diet (HFHF). In this model, FA and OZ decreased body weight, body fat, and blood lipid (TC, triglyceride [TG], low-density lipoprotein cholesterol [LDL-C], free fatty acid [FFA]) levels and increased high-density 
lipoprotein cholesterol (HDL-C). It also inhibited the accumulation of TC and TG in the liver and aorta and improved markers of oxidative stress [glutathione peroxidase (GSH-Px), catalase (CAT), glutathione reductase (GR), paraoxonase (PON1), total antioxidant capacity (TAC), malondialdehyde (MDA), lipid peroxide, vitamin E] and inflammation [tumor necrosis factor- $\alpha$ (TNF- $\alpha$ ), interleukin -6 (IL-6), C-reactive protein (CRP)] [15,18,44-48]. In particular, OZ increased the fecal excretion of TC and inhibited lipid accumulation [46,47]. In HepG2 cells, FA and OZ suppressed lipid accumulation by inhibiting the expression of fatty acid synthase (FAS), acetyl-CoA carboxylase (ACC), sterol regulatory element binding protein 2 (SREBP-2), 3-hydroxy-3-methylglutaryl coenzyme A reductase (HMGCR), and diacylglycerol O-acyltransferase 1 (DGAT1) [18,48].

Furthermore, the effects of FA and OZ on diabetes have been examined in various animal models. FA and OZ alleviate glucose intolerance and insulin resistance by decreasing glucose, glucose area under the curve (AUC), insulin, and homeostatic model assessment for insulin resistance (HOMA-IR) in animal models fed a HFHF diet or a high-carbohydrate, high-fat diet (HCHF) $[15,18,48]$. Blood glucose level and glucose intolerance were improved in $d b / d b$ mice and in a streptozotocin-induced diabetes rat model $[45,49]$. These effects are presumed to be induced by FA and OZ, which activate glucokinase activity and increase hepatic glycogen synthesis by elevating AMP-activated protein kinase (AMPK) and Akt phosphorylation in the liver [45,48].

FA has also been reported to regulate blood pressure. In HUVECs, FA treatment increased NO and cGMP levels by upregulating Akt1 and eNOS expression and decreasing superoxide levels [38]. In spontaneously hypertensive rats (SHRs), FA inhibits the activity of an angiotensin-converting enzyme (ACE), which is responsible for the conversion of the inactive form of angiotensin I to the active vasoconstrictor angiotensin II [50]. In addition, FA improved NO bioavailability by reducing oxidative stress and the production of thromboxane $\mathrm{B}_{2}\left(\mathrm{TXB}_{2}\right)[15,51]$. As a result, it was confirmed that FA has an antihypertensive effect by suppressing vasoconstriction via regulation of renin-angiotensin system (RAS) and endothelial function.

In addition, FA and OZ reduce the thickness of arterial blood vessel walls in animal models; therefore, they are expected to prevent cardiovascular diseases and to have hypolipidemic, hypoglycemic, and blood pressure-lowering effects [15] (Table 1). 
Table 1. Effects of phenolic compounds on cardiovascular and metabolic diseases.

\begin{tabular}{|c|c|c|c|c|c|}
\hline Bioactive Compounds & Food Source & $\begin{array}{c}\text { Study Subject } \\
\text { or Model }\end{array}$ & $\begin{array}{c}\text { Treatment } \\
\text { or Intervention }\end{array}$ & Results & References \\
\hline \multicolumn{6}{|c|}{ Alkylresorcinols (ARs) } \\
\hline ARs & Whole grain & $\begin{array}{l}\text { Human study } \\
\text { - Nested case control study } \\
\text { - } 64 \text { years, women }\end{array}$ & $\begin{array}{l}\text { - } 5 \text { years follow-up } \\
\text { - concentration of ARs }\end{array}$ & $\begin{array}{l}\text { - Concentration of AR homologs C17 and C19 } \\
\text { lower in subjects with IGT than that in } \\
\text { normal subjects }\end{array}$ & [33] \\
\hline ARs & Whole grain & $\begin{array}{l}\text { Human study } \\
\text { - Prospective cohort study } \\
\text { - Pregnant women (gestational } \\
\text { weeks 11-14) }\end{array}$ & $\begin{array}{l}\text { - follow-up during pregnancy } \\
\text { - total plasma AR Q1 (median } \\
66 \text { nmol/L) vs. Q4 (median } \\
706 \text { nmol/L) } \\
\text { - weekly whole grain consumption } \\
\text { Q1 (median } 1.2 \text { times/week) vs. } \\
\text { Q4 (median } 14.5 \text { times/week) }\end{array}$ & $\begin{array}{l}\text { - Frequency of whole-grain consumption lower } \\
\text { in subjects with GDM than in subjects without } \\
\text { GDM } \\
\text { - Median concentration of ARs lower in subjects } \\
\text { with GDM than in subjects without GDM } \\
\text { - Highest ARs concentration quartile with an } \\
\text { RR of } 0.50 \text { compared to lowest quartile }\end{array}$ & [34] \\
\hline $\begin{array}{l}\text { DHPPA [3-(3,5- } \\
\text { dihydroxyphenyl)-1- } \\
\text { propanoic acid] }\end{array}$ & Whole grain & $\begin{array}{l}\text { Human study } \\
\text { - Case-control study } \\
\text { - Subjects with T2D and IGT } \\
\text { - } \geq 30 \text { years }\end{array}$ & $\begin{array}{l}\text { - plasma DHPPA concentrations } \\
\text { Q1 (<6.56 nmol/L) vs. Q4 } \\
(\geq 17.98 \mathrm{nmol} / \mathrm{L})\end{array}$ & $\begin{array}{l}\text { - Negatively correlated with DHPPA } \\
\text { concentrations and odds of T2D and IGT }\end{array}$ & {$[35]$} \\
\hline $\begin{array}{l}\text { DHPPA (3-(3,5- } \\
\text { dihydroxyphenyl)-1- } \\
\text { propanoic acid) }\end{array}$ & Whole grain & $\begin{array}{l}\text { Human study } \\
\text { - Case-control study } \\
\text { - Subjects with ischemic stroke } \\
\text { - } \geq 35 \text { years }\end{array}$ & - Concentration of DHPPA & $\begin{array}{l}\text { - Negatively correlated with DHPPA } \\
\text { concentrations and odds of ischemic stroke }\end{array}$ & [16] \\
\hline
\end{tabular}


Table 1. Cont.

\begin{tabular}{|c|c|c|c|c|c|}
\hline Bioactive Compounds & Food Source & $\begin{array}{c}\text { Study Subject } \\
\text { or Model }\end{array}$ & $\begin{array}{c}\text { Treatment } \\
\text { or Intervention }\end{array}$ & Results & References \\
\hline \multicolumn{6}{|c|}{ Avenanthramides (Avns) } \\
\hline Avns & Oats & $\begin{array}{l}\text { In vivo } \\
\text { - 5-week-old, Ldlr-/- mice fed } \\
\text { with HFD }\end{array}$ & $\begin{array}{l}\text { - } 16 \text { weeks } \\
\text { - oat bran with low concentrations } \\
\text { of Avns }(8.8 \mathrm{~g} / \mathrm{kg} \text {, HFLA) or oat } \\
\text { bran with high concentrations of } \\
\text { Avns }(480 \mathrm{~g} / \mathrm{kg} \text {, HFHA) diet }\end{array}$ & $\begin{array}{l}\text { - Both oat-based diets decreased HFD-induced } \\
\text { atheroma lesions in the aortic valve } \\
\text { - HFHA administration for atheroma lesions is } \\
\text { more effective than HFLA } \\
\text { - TC level similarly reduced in both oat-based diets }\end{array}$ & [17] \\
\hline Avn-c & Oats & $\begin{array}{l}\text { In vitro } \\
\text { - Human aortic SMCs } \\
\text { and HAECs }\end{array}$ & - Avn-c 40, 80, $120 \mu \mathrm{M}$ & $\begin{array}{l}\text { - Inhibited SMC proliferation } \\
\text { - Increased NO secretion in both SMC and HAEC } \\
\text { - Upregulated eNOS mRNA expression in both } \\
\text { SMC and HAEC }\end{array}$ & [37] \\
\hline Avn-c & Oats & $\begin{array}{l}\text { In vitro } \\
\text { - A10 rat embryonic } \\
\text { aortic SMCs }\end{array}$ & - Avn-c 40, 80, $120 \mu \mathrm{M}$ & $\begin{array}{l}\text { - Arrested SMC proliferation at G1 phase } \\
\text { - Decreased phosphorylation of pRb } \\
\text { - Decreased cyclin D1 expression } \\
\text { - Increased cyclin-dependent kinase inhibitor } \\
\text { p21cip1 expression } \\
\text { - Increased expression and stability of p53 protein }\end{array}$ & [39] \\
\hline Avns & Oats & $\begin{array}{l}\text { In vitro } \\
\text { - IL-1 } \beta \text {-stimulated HAECs }\end{array}$ & - Avns 4, 20, $40 \mathrm{ng} / \mathrm{mL}$ & $\begin{array}{l}\text { - Decreased U937 monocytic cells adhesion in } \\
\text { IL-1 } \beta \text {-stimulated HAEC } \\
\text { - Suppressed expressions of ICAM-1, VCAM-1, } \\
\text { and E-selectin } \\
\text { - Suppressed secretion of proinflammatory } \\
\text { cytokines IL-6, IL-8, and MCP-1 }\end{array}$ & [40] \\
\hline Avn-c & Oats & $\begin{array}{l}\text { In vitro } \\
\text { - TNF- } \alpha \text {-stimulated HASMCs }\end{array}$ & - Avn-c 50, $100 \mathrm{ng} / \mathrm{mL}$ & $\begin{array}{l}\text { - Inhibited cell migration } \\
\text { - Suppressed increasing MMP-9 protein and } \\
\text { mRNA levels } \\
\text { - Inhibited MMP-9 enzyme activity } \\
\text { - Reduced IL-6 level } \\
\text { - Suppressed nuclear protein translocation of } \\
\text { nuclear factor kappa B (NF-kB) } \\
\text { - Reduced expression of ERK, JNK, and p38 } \\
\text { phosphorylation }\end{array}$ & [41] \\
\hline
\end{tabular}


Table 1. Cont.

\begin{tabular}{|c|c|c|c|c|c|}
\hline Bioactive Compounds & Food Source & $\begin{array}{c}\text { Study Subject } \\
\text { or Model }\end{array}$ & $\begin{array}{c}\text { Treatment } \\
\text { or Intervention }\end{array}$ & Results & References \\
\hline Avns & Oats & $\begin{array}{l}\text { In vitro } \\
\text { - IL-1 } \beta \text {-stimulated HAECs } \\
\text { - IL-1 } \beta \text {-stimulated HUVECs }\end{array}$ & $\begin{array}{l}\text { - AvnsO (oat extract) } 4,20, \\
40 \mathrm{mg} / \mathrm{mL} \\
\text { - Avn-c (Avn-c) 1, 10, 20, 40, } 100 \mu \mathrm{M} \\
\text { - CH3-Avn-c (methyl ester of Avn-c) } \\
1,10,40,100 \mu \mathrm{M}\end{array}$ & 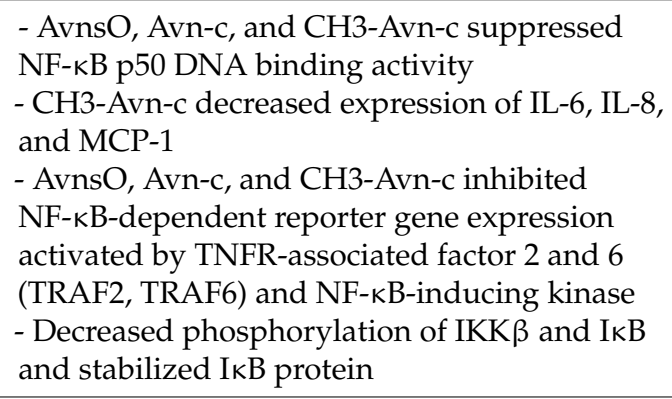 & [42] \\
\hline \multicolumn{6}{|c|}{ Ferulic acid (FA) and $\gamma$-oryzanol (OZ) } \\
\hline FA and $\mathrm{OZ}$ & Rice bran & $\begin{array}{l}\text { In vivo } \\
\text { - 4-week-old, C57BL / } 6 \text { mice } \\
\text { fed with HFD }\end{array}$ & $\begin{array}{l}\text { - } 7 \text { weeks } \\
\text { - 0.5\% FA or OZ containing diet }\end{array}$ & $\begin{array}{l}\text { - Decreased bodyweight gain in both groups } \\
\text { - Decreased blood TG, TC, and increased } \\
\text { plasma HDL-C in both groups } \\
\text { - Decreased hepatic TG and TC in both groups } \\
\text { - Decreased ME and FAS in both } \\
\text { groups-increased GSH-Px, CAT, GR, and } \\
\text { PON1 in both groups } \\
\text { - Increased fecal excretion of TC in OZ treated group }\end{array}$ & [46] \\
\hline FA and $\mathrm{OZ}$ & Rice bran & $\begin{array}{l}\text { In vivo } \\
-\mathrm{F}_{1} \mathrm{~B} \text { Golden Syrian hamsters } \\
\text { fed with } \mathrm{HCD}\end{array}$ & $\begin{array}{l}\text { - } 10 \text { weeks } \\
\text { - 0.5\% FA or OZ containing diet }\end{array}$ & $\begin{array}{l}\text { - Decreased blood TC, and non-HDL-C in both } \\
\text { groups } \\
\text { - Decreased plasma lipid hydroperoxides in } \\
\text { both groups } \\
\text { - Decreased aortic TC, and TG accumulation in } \\
\text { both groups } \\
\text { - Decreased blood TG and increased HDL-C in } \\
\text { OZ treated group } \\
\text { - Increased fecal excretion of TC and } \\
\text { coprostanol in OZ treated group } \\
\text { - Increased plasma vitamin E in FA treated group }\end{array}$ & [47] \\
\hline
\end{tabular}


Table 1. Cont.

\begin{tabular}{|c|c|c|c|c|c|}
\hline Bioactive Compounds & Food Source & $\begin{array}{c}\text { Study Subject } \\
\text { or Model }\end{array}$ & $\begin{array}{c}\text { Treatment } \\
\text { or Intervention }\end{array}$ & Results & References \\
\hline FA and $\mathrm{OZ}$ & Whole grain wheat & $\begin{array}{l}\text { In vivo } \\
\text { - SD rats (weighing 180-200 g) } \\
\text { fed with HFFD } \\
\text { In vitro } \\
\text { - HepG2 cell line } \\
\text { - FFA induced lipid/glucose } \\
\text { metabolic dysfunction } \\
\text { cell model }\end{array}$ & $\begin{array}{l}\text { In vivo } \\
\text { - } 16 \text { weeks } \\
\text { - } 0.24 \% \text { FA or } 0.71 \% \mathrm{OZ} \\
\text { containing diet } \\
\\
\text { In vitro } \\
\text { - FA or OZ } 100 \mu \mathrm{M}\end{array}$ & $\begin{array}{l}\text { In vivo } \\
\text { - Decreased body weight in both groups } \\
\text { - Decreased blood TG, TC, LDL-C, and } \\
\text { increased HDL-C in both groups } \\
\text { - Decreased fasting blood glucose and } \\
\text { HOMA-IR in both groups } \\
\text { - Decreased glucose AUC in FA treated group } \\
\text { - Increased AMPK and Akt phosphorylation in } \\
\text { liver tissues in both groups } \\
\text { In vitro } \\
\text { - Decreased TG accumulation in both groups } \\
\text { - Decreased MDA level in FA treated group } \\
\text { - Decreased AMPK phosphorylation and } \\
\text { increased Akt phosphorylation in both groups } \\
\text { - Decreased DGAT1 expression in both groups }\end{array}$ & [48] \\
\hline FA and $\mathrm{OZ}$ & Rice bran & $\begin{array}{l}\text { In vivo } \\
\text { - SD rats (weighing 350-360 g) } \\
\text { with HFFD }\end{array}$ & $\begin{array}{l}\text { In vivo } \\
\text { - } 13 \text { weeks } \\
-0.05 \% \text { FA or } 0.16 \% \mathrm{OZ} \\
\text { containing diet }\end{array}$ & $\begin{array}{l}\text { In vivo } \\
\text { - Decreased body weight and fat index in } \\
\text { both groups } \\
\text { - Decreased blood TC, TG, LDL-C, and FFA in } \\
\text { both groups } \\
\text { - Decreased hepatic TC in both groups } \\
\text { - Decreased glucose, insulin, glucose AUC, and } \\
\text { HOMA-IR in both groups } \\
\text { - Increased TAC and decreased MDA in } \\
\text { both groups } \\
\text { - Decreased CRP and IL- } 6 \text { and increased } \\
\text { adiponectin in OZ treated group } \\
\text { - Decreased TNF- } \alpha \text { in FA treated group } \\
\text { In vitro } \\
\text { - Decreased TG accumulation in OZ } \\
\text { treated group } \\
\text { - Decreased FAS, ACC, SREBP-2, HMGCR } \\
\text { expression in both groups } \\
\text { - Decreased stearoyl coA desaturase-1 } \\
\text { expression in OZ treated group }\end{array}$ & [18] \\
\hline
\end{tabular}


Table 1. Cont.

\begin{tabular}{|c|c|c|c|c|c|}
\hline Bioactive Compounds & Food Source & $\begin{array}{c}\text { Study Subject } \\
\text { or Model }\end{array}$ & $\begin{array}{c}\text { Treatment } \\
\text { or Intervention }\end{array}$ & Results & References \\
\hline $\begin{array}{l}\text { Phenolic acid fraction } \\
\text { (ethyl acetate fraction, } \\
\text { EAE) and FA }\end{array}$ & Rice bran & $\begin{array}{l}\text { In vivo } \\
\text { - 8-week-old, } \\
\text { C57BL/KsJ-db/db mice }\end{array}$ & $\begin{array}{l}\text { - } 17 \text { days } \\
\text { - EAE } 0.2 \mathrm{~g} / \mathrm{kg} \text { or FA } 0.05 \mathrm{~g} / \mathrm{kg} \\
\text { - oral administration }\end{array}$ & $\begin{array}{l}\text { - Decreased glucose and increased insulin } \\
\text { - Increased hepatic glycogen synthesis and } \\
\text { glucokinase activity } \\
\text { - Decreased TC and LDL-C }\end{array}$ & [45] \\
\hline FA & $\begin{array}{l}\text { Whole grain and } \\
\text { plant materials }\end{array}$ & $\begin{array}{l}\text { In vivo } \\
\text { - STZ-induced diabetic rats } \\
\text { (weighing 160-170 g) }\end{array}$ & $\begin{array}{l}\text { - } 45 \text { days } \\
\text { - FA 10, } 40 \mathrm{mg} / \mathrm{kg} \\
\text { - intragastric intubation }\end{array}$ & $\begin{array}{l}\text { - Decreased blood glucose } \\
\text { - Decreased blood FFA, TG, TC, and } \\
\text { phospholipids }\end{array}$ & [49] \\
\hline FA & $\begin{array}{l}\text { Rice bran and plant } \\
\text { materials }\end{array}$ & $\begin{array}{l}\text { In vivo } \\
\text { - SD rats (weighing 220-250 g) } \\
\text { fed with HCHF diet and 15\% } \\
\text { fructose in drinking water }\end{array}$ & $\begin{array}{l}\text { - } 6 \text { weeks } \\
\text { - FA } 30,60 \mathrm{mg} / \mathrm{kg} \\
\text { - oral administration }\end{array}$ & $\begin{array}{l}\text { - Decreased fasting blood glucose, glucose } \\
\text { AUC, HOMA-IR, TC, TG and increased HDL-C } \\
\text { - Decreased SBP, DBP, MAP, HR, HVR and } \\
\text { increased HBF } \\
\text { - Decreased plasma MDA and p47phox protein } \\
\text { expression } \\
\text { - Increased nitrate/nitrite levels and eNOS } \\
\text { protein expression } \\
\text { - Decreased mesenteric arterial wall thickness, } \\
\text { media to lumen ratio, cross-sectional area of } \\
\text { the media layer, and lumen area }\end{array}$ & [15] \\
\hline FA & Whole grain oats & $\begin{array}{l}\text { In vitro } \\
\text { - HUVECs }\end{array}$ & $\begin{array}{l}\text { - FA, FA derivatives (isoferulic acid, } \\
\text { hydroferulic acid, ferulic acid } \\
\text { 4-O-glucuronide, isoferulic acid } \\
\text { 3-O-sulfate, dihydroferulic acid } \\
\text { 4-O-glucuronide) } 1 \mu \mathrm{M}\end{array}$ & $\begin{array}{l}\text { - Increased NO and cGMP levels } \\
\text { - Decreased superoxide levels } \\
\text { - Increased Akt1 and eNOS expression }\end{array}$ & [38] \\
\hline FA & Plant materials & $\begin{array}{l}\text { Ex vivo } \\
\text { - } 20 \text { to } 24 \text {-week-old, SHRs }\end{array}$ & - FA $0.01,0.1,1 \mathrm{mmol} / \mathrm{ml}$ & $\begin{array}{l}\text { - Relaxed phenylephrine-induced contraction } \\
\text { - Relaxation partially supressed by removing } \\
\text { endothelium or by pretreatment with L-NAME } \\
\text { - Decreased TXB } 2 \text { production } \\
\text { - Decreased NADPH-dependent superoxide } \\
\text { anion levels } \\
\text { - Increased ACh-induced vascular relaxation }\end{array}$ & [51] \\
\hline
\end{tabular}


Table 1. Cont.

\begin{tabular}{|c|c|c|c|c|c|}
\hline Bioactive Compounds & Food Source & $\begin{array}{c}\text { Study Subject } \\
\text { or Model }\end{array}$ & $\begin{array}{c}\text { Treatment } \\
\text { or Intervention }\end{array}$ & Results & References \\
\hline FA & $\begin{array}{l}\text { Wheat bran and } \\
\text { plant materials }\end{array}$ & $\begin{array}{l}\text { In vivo } \\
\text { - 6-week-old, SHRs }\end{array}$ & $\begin{array}{l}\text { - single dose } \\
\text { - FA } 9.5 \mathrm{mg} / \mathrm{kg} \\
\text { - oral administration }\end{array}$ & $\begin{array}{l}\text { - Decreased SBP } \\
\text { - Decreased blood TC, TG, ACE activity }\end{array}$ & {$[50]$} \\
\hline
\end{tabular}

ACC, acetyl-CoA carboxylase; ACE, angiotensin converting enzyme; ACh, acetylcholine; Akt, protein kinase B; AMPK, AMP-activated protein kinase; AUC, area under the curve CAT, catalase; cGMP, cyclic guanosine monophosphate; CRP, C-reactive protein; DBP, diastolic blood pressure; DGAT1, diacylglycerol O-acyltransferase 1; eNOS, endothelial nitric oxide synthase; ERK, extracellular signal regulated kinase; FAS, fatty acid synthase; FFA, free fatty acid; GDM, gestational diabetes mellitus; GR, glutathione reductase;CSH-Px, C gluter high-car HFHA, high fat containing regular oat brans with high levels of Avns; HFHS, high-fat and high-sucrose diet; HFLA, high fat containing regular oat brans with low levels of Avns; HMGCR, 3-hydroxy-3-methylglutaryl coenzyme A reductase; Hmgcs1, 3-hydroxy-3-methylglutaryl-CoA synthase 1; HOMA-IR, homeostatic model assessment for insulin resistance; HR, heart rate; HUVECs, primary human umbilical vein endothelial cells; HVR, hindlimb vascular resistance; ICAM-1, intercellular adhesion molecule-1; IGT, impaired glucose tolerance; $\mathrm{Q}$, Quartile; IKK $\beta$, IкB kinase; IL, interleukin; IkB, inhibitor of $\mathrm{kB}$; JNK, c-Jun N-terminal kinase; LDL-C, low density lipoprotein cholesterol; L-NAME, L-NG-Nitro arginine methyl ester MAP, mean arterial pressure; MCP-1, monocyte chemoattractant protein-1; MDA, malondialdehyde; ME, malic enzyme; MMP-9, matrix metallopeptidase-9; NADPH, Nicotinamide adenine dinucleotide phosphate; NF-KB, nuclear protein translocation of nuclear factor kappa B; NO, nitric oxide; PON1, paraoxonase 1; pRb, retinoblastoma protein; RR, risk ratio; SBP systolic blood pressure; SD, Sprague-Dawley; SHRs, spontaneously hypertensive rats; SMCs, smooth muscle cells; Srebf2, sterol regulatory element binding transcription factor 2; SREBP, , total antioxidant capacity; TC, total cholesterol; TG, triglyceride; TNFR, tumor necrosis factor receptor; TNF- $\alpha$, tumor necrosis factor alpha; TRAF, tumor necrosis factor receptor-associated factor; TXB2, thromboxane B2; VCAM-1, vascular cell adhesion molecule-1. 


\section{Associations of Flavonoids with Cardiovascular and Metabolic Diseases}

Flavonoids, a subclass of phytochemicals generally originating from plant foods, can be classified into six major groups (i.e., flavanones, flavones, flavonols, flavan-3-ols, anthocyanins, and isoflavones), each of which includes various bioactive compounds [52].

The associations between flavonoids from whole grains and cardiovascular and metabolic diseases have also been demonstrated. According to $\mathrm{Hu}$ et al., the flavonoid fraction from tartary buckwheat has favorable effects on insulin and glucose metabolism in mice fed $20 \%$ high fructose water, in a dose-dependent manner, at flavonoid fraction concentrations of 200,400, and $800 \mathrm{mg} / \mathrm{kg}$ bw. The mice fed the flavonoid fraction from tartary buckwheat showed decreases in serum glucose and HOMA-IR, along with TC, LDL-C, and TG, which were induced by high fructose. In particular, the expression of insulin signaling pathway-related proteins in the liver, including insulin receptor substrate-1 (IRS1) phosphorylation, phosphoinositide 3-kinases (PI3K) (p85), protein kinase B (Akt) phosphorylation, and translocation of glucose transporter type 4 (GLUT4), increased [53]. In another study, the flavonoid fraction from tartary buckwheat improved hypertension parameters by improving insulin sensitivity in SHRs, compared to that in normal rats. Treatment with the tartary buckwheat flavonoid fraction, at a dose of $100 \mathrm{mg} / \mathrm{kg} / \mathrm{day}$, reduced the level of systolic blood pressure (SBP) in SHRs. In addition, treatment with tartary buckwheat flavonoid fractions increased the vasodilator response to insulin and reduced the phosphorylation of IRS1 with an improvement in antioxidative stress [54].

Rutin

Rutin, which is also called quercetin-3-O-rutinoside, is a flavonoid glycoside found in buckwheat, citrus fruits, onions, wine, and grapes. Quercetin is the well-known aglycone of rutin. The biological activities of rutin, such as its hypoglycemic, hypolipidemic, hepatoprotective, and anti-inflammatory effects, have been demonstrated in several previous studies $[55,56]$.

It has been reported that rutin and epigallocatechin gallate (EGCG) from buckwheat improved insulin metabolism in an in vitro model. According to Cai and Lin [57], rutin and EGCG preserve insulin signaling and regulate lipogenesis. Rutin stimulated IRS2 signaling in pancreatic $\beta$-cells and suppressed glucolipotoxic effects, via the AMPK signaling activation, to inhibit lipogenesis-related enzyme activity, and EGCG had similar effects. In addition, female adults who ate buckwheat cookies rich in rutin showed lower levels of HDL-C and TC than those in individuals who ate common buckwheat cookies, which are low in rutin, in a clinical trial [58] (Table 2). 
Table 2. Effects of flavonoids on cardiovascular and metabolic diseases.

\begin{tabular}{|c|c|c|c|c|c|}
\hline Bioactive Compounds & Food Source & $\begin{array}{c}\text { Study Subject } \\
\text { or Model }\end{array}$ & $\begin{array}{c}\text { Treatment } \\
\text { or Intervention }\end{array}$ & Results & References \\
\hline \multicolumn{6}{|c|}{ Flavonoid fraction } \\
\hline Flavonoid fraction & Tartary buckwheat & $\begin{array}{l}\text { In vivo } \\
\text { - Mice fed high fructose in } \\
\text { drinking water (weighing } \\
18-22 \mathrm{~g} \text { ) }\end{array}$ & $\begin{array}{l}\text { - } 8 \text { weeks } \\
\text { - Tartary buckwheat flavonoids } \\
200,400, \text { and } 800 \mathrm{mg} / \mathrm{kg} / \text { day } \\
\text { in drinking water }\end{array}$ & $\begin{array}{l}\text { - Improved insulin sensitivity and } \\
\text { glucose tolerance } \\
\text { - Reversed and attenuated of insulin action on } \\
\text { IRS1 phosphorylation, Akt and PI3K, and } \\
\text { GLUT4 translocation in insulin-resistant liver }\end{array}$ & {$[53]$} \\
\hline Flavonoid fraction & Tartary buckwheat & $\begin{array}{l}\text { In vivo } \\
\text { - 6-week-old, SHRs }\end{array}$ & $\begin{array}{l}\text { - } 8 \text { weeks } \\
\text { - Tartary buckwheat flavonoids } \\
100 \mathrm{mg} / \mathrm{kg} / \text { day } \\
\text { - oral administration }\end{array}$ & $\begin{array}{l}\text { - Reduced SBP } \\
\text { - Increased vasodilator response to insulin and } \\
\text { reduced IRS-1 phosphorylation at serine } 307 \\
\text { - Attenuated hypertension development by } \\
\text { reducing vascular oxidative stress }\end{array}$ & [54] \\
\hline \multicolumn{6}{|c|}{ Rutin } \\
\hline Rutin & $\mathrm{N} / \mathrm{A}$ & $\begin{array}{l}\text { In vitro } \\
\text { - Insulinoma pancreatic } \beta \text { cells } \\
\text { of RIN-m5F rat }\end{array}$ & $\begin{array}{l}\text { - EGCG or buckwheat } \\
\text { flavonoid Rutin } 0.1,10 \mu \mathrm{M}\end{array}$ & $\begin{array}{l}\text { - Stimulated IRS2 metabolic pathway in } \\
\text { pancreatic } \beta \text { cells of rat } \\
\text { - Activated AMPK pathway to suppress } \\
\text { activation of lipogenic enzyme }\end{array}$ & {$[55]$} \\
\hline Rutin & Buckwheat cookies & $\begin{array}{l}\text { Human study } \\
\text { - RCT, crossover } \\
\text { - Female adults } \\
\text { - mean age } 46 \text { years }\end{array}$ & $\begin{array}{l}\text { - } 2 \text { weeks } \\
\text { - Common buckwheat (low } \\
\text { rutin content, } 16.5 \text { mg rutin } \\
\text { equivalents/day) vs. Tartary } \\
\text { buckwheat (high rutin content, } \\
359.7 \text { mg rutin } \\
\text { equivalents/day) cookies }\end{array}$ & $\begin{array}{l}\text { - Reduced total serum cholesterol and HDL-C } \\
\text { and improved lung vital capacity } \\
\text { - Improved MPO, an indicator of inflammation }\end{array}$ & [58] \\
\hline
\end{tabular}




\section{Associations of Vitamin E with Cardiovascular and Metabolic Diseases}

According to Halliwell and Gutteridge [59], an antioxidant is defined as any substance that significantly suppresses or delays the oxidation of the substrate when existing at lower level than the oxidizable substrate. In other words, antioxidants are able to defend against oxidative damage caused by free radicals [60]. Thus, antioxidants, such as vitamin $\mathrm{E}$, contribute to cardiovascular and metabolic disease prevention by the management of oxidation-related metabolism, such as oxidative stress. Oxidative stress is linked to diabetes risk factors as well as cardiovascular risk factors, such as hyperlipidemia, hypertension, endothelial dysfunction, and vascular inflammation [61-63]. Indeed, observational studies have found a negative relationship between stroke, coronary heart disease, and mortality and dietary intake or blood levels of antioxidants $[64,65]$.

\subsection{Tocotrienol}

Tocotrienol belongs to the vitamin E group and consists of a hydrophobic carbon side chain and a 6-chromanol ring with three unsaturated bonds. Tocotrienol is more incorporated in the lipid membrane than tocopherols [66].

It has been observed that the tocotrienol-rich fraction of rice bran oil (RBO) has protective effects on glucose and lipid metabolism. In an experimental study, the administration of tocotrienol-rich fractions (TRF), for 6 weeks, decreased the level of TC, LDL-C, TG, apolipoprotein B, and glucose in hypercholesterolemic swine. In addition, tocotrienol in the blood maintained low serum lipid levels, indicating that the alteration of tocotrienols to tocopherols is not fast [67].

In hyperlipidemic albino male rats fed an atherogenic diet, TRF, derived from $\mathrm{RBO}$ at concentrations of $0,4,8,12,25$, or $50 \mathrm{mg}$ TRF/ $\mathrm{kg}$ bw/day, reduced plasma TG, TC, and LDL-C. During TRF treatment, the activity of HMG-CoA reductase also decreased [68].

In diabetic rats, the TRF of RBO and palm oil (PO), administered at a dose of $200 \mathrm{mg} / \mathrm{kg}$ bw/day for 8 weeks, showed hypoglycemic effects by lowering fasting blood glucose and $\mathrm{HbA1c}$ levels. However, blood glucose was lowered more substantially by treatment with PO-TRF than with RBO-TRF, presumably because RBO has a lower bioavailability due to the higher concentration of tocopherol, which might reduce the bioavailability of tocotrienol. In addition, TRF supplementation attenuated renal dysfunction and restored the antioxidant status in diabetic rats [69]. In another in vivo study of a diabetic model, supplement with TRF of RBO and PO improved the glycemic status and lipid parameters. Supplementation with TRF of RBO, at a dose of $400 \mathrm{mg} / \mathrm{kg}$ bw/day, and palm oil, at a dose of $200 \mathrm{mg} / \mathrm{kg}$ bw/day, reduced HbA1c, blood glucose, VLDL-C, LDL-C, TC, and TG levels compared to the corresponding levels in diabetic control mice. The levels of antioxidant enzymes decreased in the kidneys of diabetic mice groups, but these decreases were attenuated by treatment with RBO and PO-TRF [70]. In addition, TRF, isolated from RBO at a dose of $10 \mathrm{mg} / \mathrm{kg}$ bw/day, decreased LDL-C and TC by $30 \%$ and $67 \%$, respectively, decreased alkaline phosphatase (ALP) activity, and maintained low activity of glutathione-S-transferase (GST) in the mammary glands and liver of carcinogenic and hypercholesterolemic rats induced by 7,12-dimethylbenz [ $\alpha$ ]anthracene (DMBA) [71]. Tocotrienols and bran suppressed body weight gain induced by a HFD, regardless of brain oxidation or serum lipid levels [72].

Tocotrienols, from heated and stabilized rice bran with a healthy diet, also improved serum lipid profiles in those who have hypercholesterolemia. The subjects were divided into three phases and consumed their typical diet, the American Heart Association Step-1 diet, which was limited to fat intake less than 30\% energy and $300 \mathrm{mg} /$ day cholesterol intake, as well as the same diet with capsules of 25 to $200 \mathrm{mg}$ /day of TRF in sequence for 35 days each. As a result, a dose of $100 \mathrm{mg} /$ day TRF decreased serum levels of TG, TC, LDL-C, and apolipoprotein B [14]. In another clinical trial, treatment with tocotrienol for 60 days decreased serum LDL-C and TC levels in subjects with T2D and hyperlipidemia [73]. These findings suggest that tocotrienols have preventive effects on coronary heart disease, hyperlipidemia, and atherogenesis [14,73]. 


\section{2. $\alpha$-Tocopherol}

$\alpha$-Tocopherol is a liposoluble stereoisomer of vitamin E compounds. It has a chromanol ring and a 16-carbon phytyl side chain that is saturated [74]. These structures confer lipophilicity, which means the properties of chemical components dissolve in lipids, to lipid bilayers of lipoproteins or membranes [74]. Tocopherols are rich in various types of foods, while tocotrienols can be obtained from rice bran and PO $[75,76]$.

Previous studies have shown that they have preventive effects against cardiovascular disease [77]. However, $\alpha$-tocopherols inhibit the beneficial effects of tocotrienols on metabolic disorders [69]. For instance, it was reported that treatment with $\alpha$-tocopherol attenuated the TG- and TC-lowering effects of tocotrienol from rice bran in F344 rats, via the suppression of the lipid metabolism-related genes CPT-1a andCyp7a1, whereas treatment with $\alpha$-tocopherol alone did not show lipid parameter-lowering effects [78]. A comparative analysis of the effects of tocotrienol and $\alpha$-tocopherol in an in vivo rice bran model has also shown that anti-hypertensive effects were greater in the tocotrienol treatment group than in the $\alpha$-tocopherol treatment group [79]. Hence, the administration of rice bran extract containing phytosterol, tocotrienol, and $\alpha$-tocopherol did not alter body weight, lipid levels, or glucose metabolism, but it attenuated the increase in MDA in obese diabetic mice. In addition, the level of $\alpha$-tocopherol in obese diabetic mice fed rice bran extract was higher than that in obese diabetic mice fed a normal diet [80] (Table 3). 
Table 3. Effects of vitamin E on cardiovascular and metabolic diseases.

\begin{tabular}{|c|c|c|c|c|c|}
\hline Bioactive Compounds & Food Source & Study Subject or Model & Treatment or Intervention & Results & References \\
\hline \multicolumn{6}{|c|}{ Tocotrienol } \\
\hline TRF & $\mathrm{N} / \mathrm{A}$ & $\begin{array}{l}\text { In vivo } \\
\text { - 4-month-old, } \\
\text { Hypercholesterolemic swine }\end{array}$ & $\begin{array}{l}\text { - } 6 \text { weeks } \\
\text { - Corn-soybean control diet vs. control diet } \\
\text { added with } 50 \mu \mathrm{g} \text { of d-P21-tocotrienol, } \\
\text { d-P25- tocotrienol, } \gamma \text {-tocotrienol, or TRF }\end{array}$ & $\begin{array}{l}\text { - Reduced serum TG, LDL-C, TC, and } \\
\text { apolipoprotein B } \\
\text { - Reduced glucose level } \\
\text { - Level of insulin greater in treatment group }\end{array}$ & [67] \\
\hline TRF & $\mathrm{RBO}$ & $\begin{array}{l}\text { In vivo } \\
\text { - Hyperlipidemic albino male rats } \\
\text { fed with atherogenic diet } \\
\text { (weighing } 175-200 \mathrm{~g} \text { ) }\end{array}$ & $\begin{array}{l}\text { - } 1 \text { week } \\
\text { - TRF derived from rice bran oil with } \\
\text { concentrations of } 0,4,8,12,25 \text { or } 50 \mathrm{mg} \\
\text { TRF/ } \mathrm{kg} \text { bw/day } \\
\text { - mouth intubation }\end{array}$ & $\begin{array}{l}\text { - Decreased lipid parameters including TC, } \\
\text { LDL-C, and TG in a dose-dependent manner } \\
\text { - Attenuated HMG-CoA reductase activity }\end{array}$ & [68] \\
\hline TRF & $\mathrm{RBO}, \mathrm{PO}$ & $\begin{array}{l}\text { In vivo } \\
-9 \text { to } 10 \text {-week-old, STZ-induced } \\
\text { diabetic rats (weighing } 250 \mathrm{~g} \text { ) }\end{array}$ & $\begin{array}{l}\text { - } 8 \text { weeks } \\
\text { - PO and RBO derived TRF at dose of } 200 \\
\mathrm{mg} / \mathrm{kg} \text { bw/day by gavage }\end{array}$ & $\begin{array}{l}\text { - Lowered blood glucose and HbA1c levels } \\
\text { - Decreased protein in urine, serum NO, } \\
\text { TBARS, and MDA level and increased } \\
\text { SOD and catalase level }\end{array}$ & [69] \\
\hline TRF & $\mathrm{RBO}, \mathrm{PO}$ & $\begin{array}{l}\text { In vivo } \\
\text { - T2D rats (weighing 175-200g) }\end{array}$ & $\begin{array}{l}\text { - } 16 \text { weeks } \\
\text { - Supplementation with TRF of RBO at a } \\
\text { dose of } 400 \mathrm{mg} / \mathrm{kg} \mathrm{bw} / \text { day and PO at a } \\
\text { dose of } 200 \mathrm{mg} / \mathrm{kg} \mathrm{bw} / \text { day by gavage }\end{array}$ & $\begin{array}{l}\text { - Improved glycemic status and lipid } \\
\text { parameters by reducing blood glucose, } \\
\text { HbA1c, VLDL-C, LDL-C, TC, and TG levels } \\
\text { - Ameliorated lipid induced nephropathy by } \\
\text { its anti-hyperglycemic, anti-hyperlipidemic, } \\
\text { and activities of antioxidant as well as by } \\
\text { modulation of TGF- } \beta\end{array}$ & {$[70]$} \\
\hline TRF & $\mathrm{RBO}$ & $\begin{array}{l}\text { In vivo } \\
\text { - Rats treated with the chemical } \\
\text { carcinogen DMBA (weighing } \\
120 \mathrm{~g} \text { ) }\end{array}$ & $\begin{array}{l}\text { - } 6 \text { months- } 10 \mathrm{mg} \text { TRF } / \mathrm{kg} / \text { day } \\
\text { - gastric intubation }\end{array}$ & $\begin{array}{l}\text { - Decreased LDL-C and TC levels } \\
\text { induced by DMBA compared to normal } \\
\text { control levels } \\
\text { - Decreased ALP activities and } \\
\text { maintained low GST activities in liver }\end{array}$ & {$[71]$} \\
\hline Tocotrienol & Bran & $\begin{array}{l}\text { In vivo } \\
\text { - 4-week-old, HF diet treated mice }\end{array}$ & $\begin{array}{l}\text { - } 8 \text { weeks } \\
\text { - HF diet supplemented with or without } 10 \\
\text { mg of tocotrienols and } 5 \% \text { bran }\end{array}$ & $\begin{array}{l}\text { - Co-treatment with bran and tocotrienols } \\
\text { significantly supressed bodyweight gain } \\
\text { in HFD-fed mice }\end{array}$ & {$[72]$} \\
\hline
\end{tabular}


Table 3. Cont.

\begin{tabular}{|c|c|c|c|c|c|}
\hline Bioactive Compounds & Food Source & Study Subject or Model & Treatment or Intervention & Results & References \\
\hline TRF & Rice bran & $\begin{array}{l}\text { Human study } \\
\text { - RCT, parallel } \\
\text { - Hypercholesterolemic adults } \\
\text { - males }<50 \text { years and females } \\
<40 \text { years) }\end{array}$ & $\begin{array}{l}\text { - } 35 \text { days } \\
\text { - AHA Step-1 diet + TRF of rice bran 25, 50, } \\
\text { 100, } 200 \mathrm{mg} \text { /day }\end{array}$ & $\begin{array}{l}\text { - Dose of } 100 \mathrm{mg} \text { / day of TRF decreased } \\
\text { serum TC, LDL, TG, and apolipoprotein B }\end{array}$ & {$[14]$} \\
\hline Tocotrienol & $\mathrm{RBO}$ & $\begin{array}{l}\text { Human study } \\
\text { - RCT, crossover } \\
\text { - T2D with hyperlipidemia } \\
\text { - mean age } 48.5-52.6 \text { years }\end{array}$ & $\begin{array}{l}\text { - } 60 \text { days } \\
\text { - TRF capsules ( } 2 \text { capsules, } 3 \mathrm{mg} \text { TRF } / \mathrm{kg} \mathrm{bw}) \\
\text { vs. placebo }(100 \mathrm{mg} \text { of TRF-free RBO/kg bw) } \\
\text { - Group A: TRF in the first phase and color } \\
\text { matched placebo capsules in the second phase } \\
\text { - Group B: TRF in both first and second phases }\end{array}$ & $\begin{array}{l}\text { - TRF supplement showed reduction of } 23 \\
\text { to } 42 \% \text { in serum lipid }\end{array}$ & [73] \\
\hline \multicolumn{6}{|c|}{$\alpha$-tocopherol and torotrienol } \\
\hline $\begin{array}{l}\alpha \text {-tocopherol and } \\
\text { torotrienol }\end{array}$ & Rice bran & $\begin{array}{l}\text { In vivo } \\
\text { - 6-week-old, F344/slc male rats }\end{array}$ & $\begin{array}{l}\text { - } 21 \text { days } \\
\text { - Group 1, normal chow diet; Group 2, WD; } \\
\text { Group 3, WD with } \alpha \text {-Toc } 50 \mathrm{mg} / \text { day; Group 4, } \\
\text { WD with rice bran tocotrienol } 11.1 \mathrm{mg} / \text { day; } \\
\text { Group 5, WD with } \alpha \text {-tocopherol } 50 \mathrm{mg} / \text { day } \\
\text { and rice bran tocotrienol } 11.1 \mathrm{mg} / \text { day } \\
\text { - oral administration }\end{array}$ & $\begin{array}{l}\text { - } \alpha \text {-tocopherol attenuated lowering effects } \\
\text { of TC and TG rice bran tocotrienol } \\
\text { - } \alpha \text {-tocopherol alone did not attenuate } \\
\text { hyperlipidemic effects } \\
\text { - Rice bran tocotrienol-induced gene } \\
\text { expression of CPT-1a and Cyp7a1 } \\
\text { reduced by } \alpha \text {-tocopherol }\end{array}$ & [78] \\
\hline $\begin{array}{l}\alpha \text {-tocopherol and } \\
\text { torotrienol }\end{array}$ & Rice bran & $\begin{array}{l}\text { In vivo } \\
\text { - C57BL/6 ApoE-deficient mice }\end{array}$ & $\begin{array}{l}\text { - } 24 \text { weeks } \\
\text { - } \alpha \text {-tocopherol, TRF, didesmethyl tocotrienol } \\
\text { (d-P25-tocotrienol) with low or high fat diets }\end{array}$ & $\begin{array}{l}\text { - Reduced TC and LDL-C in TRF25 and } \\
\text { d-P25-T3 group } \\
\text { - Reduced atherosclerotic lesion size }\end{array}$ & [79] \\
\hline $\begin{array}{l}\alpha \text {-tocopherol and } \\
\text { torotrienol }\end{array}$ & Rice bran & $\begin{array}{l}\text { In vivo } \\
\text { - 6-week-old, KKAy diabetic mice }\end{array}$ & $\begin{array}{l}\text { - } 6 \text { weeks } \\
\text { - normal diet (DM group), a diet including } \\
0.1 \% \text { Ricetrienol (RT group), non-diabetic } \\
\text { C57BL mice (C group) } \\
\text { - 0.1\% Ricetrienol (crude lipophilic rice bran } \\
\text { extract) contains } \alpha \text {-tocopherol, tocotrienol, } \\
\text { phytosterol }\end{array}$ & $\begin{array}{l}\text { - Rice bran treatment did not alter } \\
\text { bodyweight, lipid levels, or glucose } \\
\text { metabolism } \\
\text { - Elevation of the level of MDA in plasma } \\
\text { significantly attenuated by rice bran } \\
\text { - The level of } \alpha \text {-tocopherol in plasma of } \\
\text { RT group was significantly higher } \\
\text { compared to that in DM group }\end{array}$ & [80] \\
\hline
\end{tabular}




\section{Associations of Fiber with Cardiovascular and Metabolic Diseases}

Dietary fiber is a carbohydrate polymer in plants that is not decomposed by the human digestive enzymes [81,82]. It helps to improve gut health by facilitating the excretion of feces and producing metabolites that are fermented by the gut microbiota and are beneficial to the gut environment $[81,83]$. In addition, it is known to improve various metabolic and cardiovascular diseases by suppressing the absorption of glucose and cholesterol, thereby reducing blood glucose, blood lipids, and body weight [84-88]. Whole grains also contain high levels of dietary fiber. A meta-analysis of various cohort studies has shown that the risk ratio for T2D is lower for cereal fiber than for fruit fiber, proving the superiority of whole grain dietary fiber [89]. In addition, the FDA has approved the claim that the consumption of soluble fiber, derived from whole grain oats, may decrease the risk of heart diseases when combined with a low saturated fat and cholesterol diet [90].

$\beta$-Glucan

The representative dietary fiber present in the whole grain is $\beta$-glucan $[(1 \rightarrow 3)(1 \rightarrow 4)$ $\beta$-D-glucan] and $\beta$-Glucan is a water-soluble fiber. As a specific indicator compound with various activities in oats and barley, its effects and mechanisms on metabolic and cardiovascular diseases have been studied [91].

First, oat and barley $\beta$-glucan effectively reduce blood lipid levels. Several human studies have reported that dietary fiber intake reduces blood TC and LDL-C levels [92-94]. As the cholesterol precursor lathosterol and the phytosterol campesterol decrease, it could be hypothesized that dietary fiber inhibits cholesterol synthesis and absorption [94]. In addition, $\beta$-glucan effectively inhibits lipid accumulation and absorption by reducing the intestinal uptake of fatty acids and inhibiting fatty acid synthesis pathways, such as ACC and FAS, as well as the expression of transport proteins, such as intestinal fatty acid binding protein (i-FABP) and fatty acid transport protein 4 (FATP4), as determined by preclinical studies [13].

Studies have also shown that $\beta$-glucan reduces blood glucose levels and improves insulin resistance. In animal studies, the administration of oat $\beta$-glucan reduced blood glucose, insulin, and fructosamine and improved glucose intolerance and insulin resistance $[95,96]$. Similarly, in clinical trials, in subjects with metabolic risk factors, oat $\beta$-glucan intake improved glucose intolerance and insulin sensitivity [92,97]. This is expected to be mainly due to the inhibition of glucose absorption by $\beta$-glucan. Specifically, in a diabetic animal model, the disaccharidase activity of the small intestinal mucosa is reduced, thereby delaying glucose digestion and, consequently, suppressing the rapid increase in blood glucose [95]. In addition, $\beta$-glucan, a representative soluble fiber, increases the viscosity of gastric contents, delaying the overall digestive process, including gastric emptying, thereby suppressing insulin secretion and increasing postprandial blood glucose $[85,98]$ (Table 4). 
Table 4. Effects of fiber on cardiovascular and metabolic diseases.

\begin{tabular}{|c|c|c|c|c|c|}
\hline Bioactive Compounds & Food Source & Study Subject or Model & Treatment or Intervention & Results & References \\
\hline \multicolumn{6}{|c|}{$\beta$-glucan } \\
\hline$\beta$-glucan & Whole grain oats & $\begin{array}{l}\text { Human study } \\
\text { - RCT, crossover } \\
\text { - Mildly hypercholesterolemic subjects } \\
\text { - 18-65 years }\end{array}$ & $\begin{array}{l}\text { - } 4 \text { weeks } \\
\text { - } \beta \text {-glucan } 5 \mathrm{~g}\end{array}$ & $\begin{array}{l}\text { - Decreased TC, LDL-C, TC/HDL-C ratio } \\
\text { - Decreased lathosterol and campesterol }\end{array}$ & [94] \\
\hline$\beta$-glucan & Oat gum ( $80 \% \beta$-glucan) & $\begin{array}{l}\text { Human study } \\
\text { - RCT, crossover } \\
\text { - Hypercholesterolemic subjects }\end{array}$ & $\begin{array}{l}\text { - } 4 \text { weeks } \\
\text { - oat gum ( } 2.9 \mathrm{~g} \beta \text {-glucan) }\end{array}$ & - Decreased TC and LDL-C & [93] \\
\hline$\beta$-glucan & Whole grain oats & $\begin{array}{l}\text { Human study } \\
\text { - RCT, parallel } \\
\text { - Hypercholesterolemic subjects } \\
-18-70 \text { years }\end{array}$ & $\begin{array}{l}\text { - } 3 \text { weeks } \\
\text { - } \beta \text {-glucan } 5 \mathrm{mg}\end{array}$ & $\begin{array}{l}\text { - Decreased TC } \\
\text { - Decreased postprandial glucose and insulin }\end{array}$ & [92] \\
\hline$\beta$-glucan & Whole grain oats & $\begin{array}{l}\text { In vivo } \\
\text { - SD rats (weighing 150-170 g) }\end{array}$ & $\begin{array}{l}\text { - } 4 \text { weeks } \\
\text { - } \beta \text {-glucan } 312.5 \mathrm{mg} / \mathrm{kg} \\
\text { - oral administration }\end{array}$ & $\begin{array}{l}\text { - Decreased bodyweight gain } \\
\text { - Decreased fasting blood glucose } \\
\text { - Increased ISI and NEFA } \\
\text { - Increased portion of Bifidobacterium and } \\
\text { Lactobacillus in colon contents }\end{array}$ & [96] \\
\hline$\beta$-glucan & Whole grain oats & $\begin{array}{l}\text { In vivo } \\
\text { - 4-week-old, HSHF diet and } \\
\text { STZ-induced diabetic mice }\end{array}$ & $\begin{array}{l}\text { - } 6 \text { weeks } \\
\text { - } \beta \text {-glucan 2000, 1200, or } 800 \mathrm{mg} / \mathrm{kg} \\
\text { - oral administration }\end{array}$ & $\begin{array}{l}\text { - Decreased fasting glucose and fructosamine } \\
\text { - Increased fasting insulin and decreased IAI } \\
\text { - Decreased activity of disaccharidase (sucrose, } \\
\text { lactase, maltase) in small intestine mucosa }\end{array}$ & [95] \\
\hline$\beta$-glucan & Whole grain oat & $\begin{array}{l}\text { Human study } \\
\text { - RCT, parallel } \\
\text { - Subjects with elevated blood pressure } \\
\text { - } \geq 40 \text { years }\end{array}$ & $\begin{array}{l}\text { - } 12 \text { weeks } \\
\text { - Foods containing oat } \beta \text {-glucan } \\
\text { ( } 7.7 \mathrm{~g} / \text { serving) }\end{array}$ & $\begin{array}{l}\text { - Decreased SBP in subjects with BMI above } \\
\text { the median }\left(31.5 \mathrm{~kg} / \mathrm{m}^{2}\right) \\
\text { - Decreased glucose AUC, fasting insulin, } \\
\text { peak insulin, and insulin AUC }\end{array}$ & [97] \\
\hline \multicolumn{6}{|c|}{$\begin{array}{l}\text { ACC, acetyl-CoA carboxylase; AUC, area under the curve; BMI, body mass index; FAS, fatty acid synthase; HDL-C, high-density lipoprotein cholesterol; HSHF, high-sucrose and high-fat } \\
\text { diet; IAI, insulin activity index; i-FABP, intestinal fatty acid binding protein; FATP, fatty acid transport protein 4; ISI, insulin sensitivity index; LDL-C, low-density lipoprotein cholesterol } \\
\text { NEFA, non-esterified fatty acids; RCT, randomized, controlled clinical trial; SBP, systolic blood pressure; SCFA, short-chain fatty acid; SD, Sprague-Dawley; STZ, streptozotocin; TC, total } \\
\text { cholesterol; TG, triglyceride. }\end{array}$} \\
\hline
\end{tabular}




\section{Conclusions}

Major bioactive compounds abundant in whole grains, such as polyphenols, flavonoids, antioxidants, and fiber, have been demonstrated to have preventive effects on cardiovascular and metabolic diseases. Alkylresorcinols, aventhramides, ferulic acid, and $\gamma$-oryzanol are representative polyphenols in whole grains, especially in rice bran or oat, and show preventive effects against impaired glucose intolerance, diabetes, vascular diseases, hypertension, and dyslipidemia. Rutin, one of the types a flavonoid rich in buckwheat, improved insulin sensitivity, glucose tolerance, lipid metabolism, and hypertension-related parameters. Tocotrienol, which are antioxidants that are generally derived from $\mathrm{RBO}$ and $\alpha$-tocopherol, found in a variety of foods, also show hypolipidemic and hypoglycemic effects in vivo and in humans. In particular, the anti-hyperlipidemic effects of tocotrienol are attenuated by interactions with $\alpha$-tocopherol. Soluble fiber, including $\beta$-glucan from oat and barley, decreased lipid profiles by inhibition of cholesterol or fatty acid synthesis and absorption, as well as blood glucose levels, with improved glucose intolerance and insulin resistance.

As described above, the preventive effects of bioactive compounds derived from whole grains on cardiovascular and metabolic diseases are well-established; therefore, whole grains are often consumed as a healthy food. Indeed, various studies have revealed that whole grain food consumption improves metabolic parameters. In a meta-analysis, intake of 3 servings, or $90 \mathrm{~g}$, of whole grains per day was related to $19 \%$ and $22 \%$ reduced risks of coronary artery disease and cardiovascular diseases, respectively [25]. In addition, an overall inverse association between whole grain and metabolic syndrome has been identified, while a positive association has been detected for refined grain consumption in a meta-analysis of several observational studies [99].

The favorable effects of whole grain foods on cardiovascular and metabolic diseases have also been observed in clinical intervention studies. A higher consumption of a whole grain-enriched diet was associated with higher concentrations of lipid metabolites and decreased postprandial insulin levels compared to those for the intake of a refined wheat cereal diet in subjects who have metabolic syndrome [100]. Supplementation of a lowfiber diet with oat bran also improved non-HDL-C and TC compared to levels for the control diet [101]. The consumption of tartary buckwheat, a whole grain food, decreased the levels of insulin, LDL-C, and TC in patients who have T2D [102]. However, a nonsignificant association was observed in another study. Whole grain consumption did not alter metabolic disease parameters, anthropometric measurements, or body composition in those who were healthy, overweight, or obese and consumed whole grain wheat for 8 weeks compared to parameter values for the refined wheat product consumption group [103]. However, the amount of intake and study duration varies by studies. In addition, specific doses of bioactive compounds derived from whole grain foods and appropriate treatment duration of the studies described in this review are also still inconclusive. Thus, more studies of the relationship between the intake of bioactive compounds or whole grains and metabolic and cardiovascular diseases for specific guidelines should be conducted.

Taken together, these results indicate that bioactive compounds rich in whole grains, including alkylresorcinols, avenanthramides, ferulic acid, $\gamma$-oryzanol, rutin, tocotrienol, $\alpha$-tocopherol, and $\beta$-glucan, as well as whole grains as a whole food, play important roles in the prevention of cardiovascular and metabolic diseases. However, data for the effects of individual bioactive compounds from well-designed human studies are still lacking, and the interactive effects of various bioactive compounds on the regulation of cardiovascular and metabolic diseases are still unclear. Since plant-derived components are widely used as new nutritional and pharmaceutical supplements, owing to their minimal side effects, further studies are required. In conclusion, the intake of whole grain-derived bioactive compounds, for cardiovascular and metabolic disease prevention, may be a useful dietary strategy. 
Author Contributions: Conceptualization, S.C. and S.-H.P.; Methodology, S.C. and S.-H.P.; Investigation, S.C., J.-T.H. and S.-H.P.; Data Curation, S.C., J.-T.H. and S.-H.P.; Writing-Original Draft Preparation, S.C.; Writing-Review \& Editing, S.-H.P.; Supervision, S.-H.P. All authors have read and agreed to the published version of the manuscript.

Funding: This study was funded by a research grant from the Korea Food Research Institute (Project Number: E0210601), Republic of Korea.

Institutional Review Board Statement: Not applicable.

Informed Consent Statement: Not applicable.

Data Availability Statement: Not applicable.

Acknowledgments: This study was supported by a Korea Food Research Institute grant (Project Number: E0210601).

Conflicts of Interest: The authors declare no conflict of interest.

\section{References}

1. Roth, G.A.; Mensah, G.A.; Johnson, C.O.; Addolorato, G.; Ammirati, E.; Baddour, L.M.; Barengo, N.C.; Beaton, A.Z.; Benjamin, E.J.; Benziger, C.P.; et al. Global burden of cardiovascular diseases and risk factors, 1990-2019. J. Am. Coll. Cardiol. 2020, 76, 2982-3021. [CrossRef]

2. Musinguzi, G.; Ndejjo, R.; Ssinabulya, I.; Bastiaens, H.; van Marwijk, H.; Wanyenze, R.K. Cardiovascular risk factor mapping and distribution among adults in mukono and buikwe districts in Uganda: Small area analysis. BMC Cardiovasc. Disord. 2020, 20, 284. [CrossRef] [PubMed]

3. Olatona, F.A.; Onabanjo, O.O.; Ugbaja, R.N.; Nnoaham, K.E.; Adelekan, D.A. Dietary habits and metabolic risk factors for non-communicable diseases in a University undergraduate population. J. Health Popul. Nutr. 2018, 37, 21. [CrossRef] [PubMed]

4. Grundy, S.M. Metabolic syndrome pandemic. Arter. Thromb. Vasc. Biol. 2008, 28, 629-636. [CrossRef] [PubMed]

5. Venkatakrishnan, K.; Chiu, H.-F.; Wang, C.K. Extensive review of popular functional foods and nutraceuticals against obesity and its related complications with a special focus on randomized clinical trials. Food Funct. 2019, 10, 2313-2329. [CrossRef]

6. Alkhatib, A.; Tsang, C.; Tiss, A.; Bahorun, T.; Arefanian, H.; Barake, R.; Khadir, A.; Tuomilehto, J. Functional foods and lifestyle approaches for diabetes prevention and management. Nutrients 2017, 9, 1310. [CrossRef]

7. Trumbo, P.; Schlicker, S.; Yates, A.A.; Poos, M. Food, nutrition board of the institute of medicine TNA: Dietary reference intakes for energy, carbohydrate, fiber, fat, fatty acids, cholesterol, protein and amino acids. J. Am. Diet Assoc. 2002, 102, $1621-1630$. [CrossRef]

8. Jiang, H.; Zhang, J.; Du, W.; Su, C.; Zhang, B.; Wang, H. Energy intake and energy contributions of macronutrients and major food sources among Chinese adults: CHNS 2015 and CNTCS 2015. Eur. J. Clin. Nutr. 2021, 75, 314-324. [CrossRef]

9. Gose, M.; Krems, C.; Heuer, T.; Hoffmann, I. Trends in food consumption and nutrient intake in Germany between 2006 and 2012 : Results of the German National Nutrition Monitoring (NEMONIT). Br. J. Nutr. 2016, 115, 1498-1507. [CrossRef]

10. Wright, J.D.; Wang, C.Y. Trends in intake of energy and macronutrients in adults from 1999-2000 through 2007-2008. NCHS Data Brief 2010, 49, 1-8.

11. Sabença, C.; Ribeiro, M.; Sousa, T.; Poeta, P.; Bagulho, A.; Igrejas, G. Wheat/Gluten-Related Disorders and Gluten-Free Diet Misconceptions: A Review. Foods 2021, 10, 1765. [CrossRef]

12. Slavin, J.L.; Jacobs, D.; Marquart, L.; Wiemer, K. The role of whole grains in disease prevention. J. Am. Diet. Assoc. 2001, 101, 780-785. [CrossRef]

13. Drozdowski, L.A.; Reimer, R.A.; Temelli, F.; Bell, R.C.; Vasanthan, T.; Thomson, A.B. Beta-glucan extracts inhibit the in vitro intestinal uptake of long-chain fatty acids and cholesterol and down-regulate genes involved in lipogenesis and lipid transport in rats. J. Nutr. Biochem. 2010, 21, 695-701. [CrossRef]

14. Qureshi, A.A.; Sami, S.A.; Salser, W.A.; Khan, F.A. Dose-dependent suppression of serum cholesterol by tocotrienol-rich fraction (trf25) of rice bran in hypercholesterolemic humans. Atherosclerosis 2002, 161, 199-207. [CrossRef]

15. Senaphan, K.; Kukongviriyapan, U.; Sangartit, W.; Pakdeechote, P.; Pannangpetch, P.; Prachaney, P.; Greenwald, S.E.; Kukongviriyapan, V. Ferulic acid alleviates changes in a rat model of metabolic syndrome induced by high-carbohydrate, high-fat diet. Nutrients 2015, 7, 6446-6464. [CrossRef]

16. Sun, T.; Zhang, Y.; Huang, H.; Wang, X.; Zhou, L.; Li, S.; Huang, S.; Xie, C.; Wen, Y.; Zhu, Y.; et al. Plasma alkylresorcinol metabolite, a biomarker of whole-grain wheat and rye intake, and risk of ischemic stroke: A case-control study. Am. J. Clin. Nutr. 2019, 109, 1-7. [CrossRef]

17. Thomas, M.; Kim, S.; Guo, W.; Collins, F.W.; Wise, M.L.; Meydani, M. High levels of avenanthramides in oat-based diet further suppress high fat diet-induced atherosclerosis in Ldlr-/- Mice. J. Agric. Food Chem. 2018, 66, 498-504. [CrossRef]

18. Wang, O.; Liu, J.; Cheng, Q.; Guo, X.; Wang, Y.; Zhao, L.; Zhou, F.; Ji, B. Effects of ferulic acid and gamma-oryzanol on high-fat and high-fructose diet-induced metabolic syndrome in rats. PLoS ONE 2015, 10, e0118135.

19. Ganesan, K.; Xu, B. Polyphenol-rich lentils and their health promoting effects. Int. J. Mol. Sci. 2017, 18, 2390. [CrossRef] 
20. Surampudi, P.; Enkhmaa, B.; Anuurad, E.; Berglund, L. Lipid lowering with soluble dietary fiber. Curr. Atheroscler. Rep. 2016, 18, 75. [CrossRef]

21. Yu, K.; Ke, M.Y.; Li, W.H.; Zhang, S.Q.; Fang, X.C. The impact of soluble dietary fibre on gastric emptying, postprandial blood glucose and insulin in patients with Type 2 diabetes. Asia Pac. J. Clin. Nutr. 2014, 23, 210-218. [PubMed]

22. Jiang, Q. Natural forms of vitamin e: Metabolism, antioxidant, and anti-inflammatory activities and their role in disease prevention and therapy. Free Radic. Biol. Med. 2014, 72, 76-90. [CrossRef] [PubMed]

23. Reynolds, A.; Mann, J.; Cummings, J.; Winter, N.; Mete, E.; Morenga, L.T. Carbohydrate quality and human health: A series of systematic reviews and meta-analyses. Lancet 2019, 393, 434-445. [CrossRef]

24. Benisi-Kohansal, S.; Saneei, P.; Salehi-Marzijarani, M.; Larijani, B.; Esmaillzadeh, A. Whole-grain intake and mortality from all causes, cardiovascular disease, and cancer: A systematic review and dose-response meta-analysis of prospective cohort studies. Adv. Nutr. 2016, 7, 1052-1065. [CrossRef]

25. Aune, D.; Keum, N.; Giovannucci, E.; Fadnes, L.T.; Boffetta, P.; Greenwood, D.C.; Tonstad, S.; Vatten, L.J.; Riboli, E.; Norat, T. Whole grain consumption and risk of cardiovascular disease, cancer, and all cause and cause specific mortality: Systematic review and dose-response meta-analysis of prospective studies. BMJ 2016, 353, i2716. [CrossRef]

26. Velderrain-Rodríguez, G.R.; Palafox-Carlos, H.; Wall-Medrano, A.; Ayala-Zavala, J.F.; Chen, C.Y.; Robles-Sánchez, M.; AstiazaranGarcía, H.; Alvarez-Parrilla, E.; González-Aguilar, G.A. Phenolic compounds: Their journey after intake. Food Funct. 2014, 5, 189-197. [CrossRef]

27. Cory, H.; Passarelli, S.; Szeto, J.; Tamez, M.; Mattei, J. The Role of polyphenols in human health and food systems: A mini-review. Front. Nutr. 2018, 5, 87. [CrossRef]

28. Tangney, C.C.; Rasmussen, H.E. Polyphenols, inflammation, and cardiovascular disease. Curr. Atheroscler. Rep. $2013,15,324$. [CrossRef]

29. Baerson, S.R.; Schröder, J.; Cook, D.; Rimando, A.M.; Pan, Z.; Dayan, F.E.; Noonan, B.P.; Duke, S.O. Alkylresorcinol biosynthesis in plants: New insights from an ancient enzyme family? Plant. Signal. Behav. 2010, 5, 1286-1289. [CrossRef]

30. Quistad, G.B.; Staiger, L.E.; Schooley, D.A. Environmental degradation of the miticide cycloprate (Hexadecyl Cyclopropanecarboxylate). 1. Rat metabolism. J. Agric. Food Chem. 1978, 26, 60-66. [CrossRef]

31. Zhao, Z.; Moghadasian, M.H. Chemistry, natural sources, dietary intake and pharmacokinetic properties of ferulic acid: A review. Food Chem. 2008, 109, 691-702. [CrossRef]

32. Scavariello, E.M.; Arellano, D.B. Gamma-oryzanol: An important component in rice brain oil. Arch. Latinoam. Nutr. 1998, 48, 7-12.

33. Savolainen, O.; Lind, M.V.; Bergström, G.; Fagerberg, B.; Sandberg, A.S.; Ross, A. Biomarkers of food intake and nutrient status are associated with glucose tolerance status and development of type 2 Diabetes in older swedish women. Am. J. Clin. Nutr. 2017, 106, 1302-1310. [CrossRef]

34. Tryggvadottir, E.A.; Halldorsson, T.I.; Landberg, R.; Hrolfsdottir, L.; Birgisdottir, B.E.; Magnusdottir, O.K.; Hreidarsdottir, I.T.; Hardardottir, H.; Gunnarsdottir, I. Higher alkylresorcinol concentrations, a consequence of whole-grain intake, are inversely associated with gestational Diabetes mellitus in Iceland. J. Nutr. 2021, 151, 1159-1166. [CrossRef]

35. Sun, T.; Rong, Y.; Hu, X.; Zhu, Y.; Huang, H.; Chen, L.; Li, P.; Li, S.; Yang, W.; Cheng, J.; et al. Plasma alkylresorcinol metabolite, a biomarker of whole-grain wheat and rye intake, and risk of type 2 Diabetes and impaired glucose regulation in a Chinese population. Diabetes Care 2018, 41, 440-445. [CrossRef]

36. Oishi, K.; Yamamoto, S.; Itoh, N.; Nakao, R.; Yasumoto, Y.; Tanaka, K.; Kikuchi, Y.; Fukudome, S.; Okita, K.; Takano-Ishikawa, Y. Wheat alkylresorcinols suppress high-fat, high-sucrose diet-induced obesity and glucose intolerance by increasing insulin sensitivity and cholesterol excretion in male mice. J. Nutr. 2015, 145, 199-206. [CrossRef]

37. Nie, L.; Wise, M.L.; Peterson, D.M.; Meydani, M. Avenanthramide, a polyphenol from oats, inhibits vascular smooth muscle cell proliferation and enhances nitric oxide production. Atherosclerosis 2006, 186, 260-266. [CrossRef]

38. Serreli, G.; Le Sayec, M.; Thou, E.; Lacour, C.; Diotallevi, C.; Dhunna, M.A.; Deiana, M.; Spencer, J.P.E.; Corona, G. Ferulic acid derivatives and avenanthramides modulate endothelial function through maintenance of nitric oxide balance in HUVEC cells Nutrients 2021, 13, 2026. [CrossRef]

39. Nie, L.; Wise, M.; Peterson, D.; Meydani, M. Mechanism by which avenanthramide-c, a polyphenol of oats, blocks cell cycle progression in vascular smooth muscle cells. Free Radic. Biol. Med. 2006, 41, 702-708. [CrossRef]

40. Liu, L.; Zubik, L.; Collins, F.W.; Marko, M.; Meydani, M. The antiatherogenic potential of oat phenolic compounds. Atherosclerosis 2004, 175, 39-49. [CrossRef]

41. Park, J.; Choi, H.; Abekura, F.; Lim, H.S.; Im, J.H.; Yang, W.S.; Hwang, C.W.; Chang, Y.C.; Lee, Y.C.; Park, N.G.; et al. Avenanthramide $\mathrm{C}$ suppresses matrix metalloproteinase-9 expression and migration through the mapk/nf-kb signaling pathway in TNF-alpha-activated HASMC cells. Front. Pharmacol. 2021, 12, 621854. [CrossRef]

42. Guo, W.; Wise, M.L.; Collins, F.W.; Meydani, M. Avenanthramides, polyphenols from oats, inhibit IL-1beta-induced NF-KappaB activation in endothelial cells. Free Radic. Biol. Med. 2008, 44, 415-429. [CrossRef]

43. Sombutsuwan, P.; Jirattisakul, A.; Nakornsadet, A.; Akepratumchai, S.; Chumsantea, S.; Pojjanapornpun, S.; Lilitchan, S.; Krisnangkura, K.; Aryusuk, K. A simple and efficient method for synthesis and extraction of ethyl ferulate from gamma-oryzanol. J. Oleo Sci. 2021, 70, 757-767. [CrossRef]

44. Raj, P.; Ames, N.; Thandapilly, S.J.; Yu, L.; Netticadan, T. The effects of oat ingredients on blood pressure in spontaneously hypertensive rats. J. Food Biochem. 2020, 44, e13402. [CrossRef] 
45. Jung, E.H.; Kim, S.R.; Hwang, I.K.; Ha, T.Y. Hypoglycemic effects of a phenolic acid fraction of rice bran and ferulic acid in C57BL/KsJ-db/db mice. J. Agric. Food Chem. 2007, 55, 9800-9804. [CrossRef]

46. Jin Son, M.; Rico, C.W.; Hyun, N.S.; Young, K.M. Influence of Oryzanol and Ferulic acid on the lipid metabolism and antioxidative status in high fat-fed mice. J. Clin. Biochem. Nutr. 2010, 46, 150-156. [CrossRef]

47. Wilson, T.A.; Nicolosi, R.J.; Woolfrey, B.; Kritchevsky, D. Rice bran oil and oryzanol reduce plasma lipid and lipoprotein cholesterol concentrations and aortic cholesterol ester accumulation to a greater extent than ferulic acid in hypercholesterolemic hamsters. $J$. Nutr. Biochem. 2007, 18, 105-112. [CrossRef]

48. Guo, X.X.; Zeng, Z.; Qian, Y.Z.; Qiu, J.; Wang, K.; Wang, Y.; Ji, B.P.; Zhou, F. Wheat flour, enriched with gamma-oryzanol, phytosterol, and ferulic acid, alleviates lipid and glucose metabolism in high-fat-fructose-fed rats. Nutrients 2019, $11,1697$. [CrossRef] [PubMed]

49. Balasubashini, M.S.; Rukkumani, R.; Menon, V.P. Protective effects of ferulic acid on hyperlipidemic diabetic rats. Acta Diabetol. 2003, 40, 118-122. [CrossRef] [PubMed]

50. Ardiansyah; Ohsaki, Y.; Shirakawa, H.; Koseki, T.; Komai, M. Novel effects of a single administration of ferulic acid on the regulation of blood pressure and the hepatic lipid metabolic profile in stroke-prone spontaneously hypertensive rats. J. Agric. Food Chem. 2008, 56, 2825-2830.

51. Suzuki, A.; Yamamoto, M.; Jokura, H.; Fujii, A.; Tokimitsu, I.; Hase, T.; Saito, I. Ferulic acid restores endothelium-dependent vasodilation in aortas of spontaneously hypertensive rats. Am. J. Hypertens. 2007, 20, 508-513. [CrossRef] [PubMed]

52. Kent, K.; Charlton, K.; O'Sullivan, T.; Oddy, W.H. Estimated intake and major food sources of flavonoids among australian adolescents. Eur. J. Nutr. 2020, 59, 3841-3856. [CrossRef] [PubMed]

53. Hu, Y.; Hou, Z.; Yi, R.; Wang, Z.; Sun, P.; Li, G.; Zhao, X.; Wang, Q. Tartary buckwheat flavonoids ameliorate high fructose-induced insulin resistance and oxidative stress associated with the insulin signaling and Nrf2/HO-1 pathways in mice. Food Funct. 2017, 8, 2803-2816. [CrossRef] [PubMed]

54. Hou, Z.; Hu, Y.; Yang, X.; Chen, W. Antihypertensive effects of tartary buckwheat flavonoids by improvement of vascular insulin sensitivity in spontaneously hypertensive rats. Food Funct. 2017, 8, 4217-4228. [CrossRef]

55. Ghorbani, A. Mechanisms of antidiabetic effects of flavonoid rutin. Biomed. Pharmacother. 2017, 96, 305-312. [CrossRef]

56. Da Silva, A.B.; Cerqueira Coelho, P.L.; das Neves Oliveira, M.; Oliveira, J.L.; Oliveira Amparo, J.A.; da Silva, K.C.; Soares, J.R.P.; Pitanga, B.P.S.; Dos Santos, S.C.; de Faria, L.G.P.; et al. The flavonoid rutin and its aglycone quercetin modulate the microglia inflammatory profile improving antiglioma activity. Brain Behav. Immun. 2020, 85, 170-185. [CrossRef]

57. Cai, E.P.; Lin, J.K. Epigallocatechin gallate (egcg) and rutin suppress the glucotoxicity through activating IRS2 and AMPK signaling in rat pancreatic beta cells. J. Agric. Food Chem. 2009, 57, 9817-9827. [CrossRef]

58. Wieslander, G.; Fabjan, N.; Vogrincic, M.; Kreft, I.; Janson, C.; Spetz-Nyström, U.; Vombergar, B.; Tagesson, C.; Leanderson, P.; Norbäck, D. Eating buckwheat cookies is associated with the reduction in serum levels of myeloperoxidase and cholesterol: A double blind crossover study in day-care centre staffs. Tohoku J. Exp. Med. 2011, 225, 123-130. [CrossRef]

59. Halliwell, B.; Gutteridge, J.M. The definition and measurement of antioxidants in biological systems. Free Radic. Biol. Med. 1995, 18, 125-126. [CrossRef]

60. Wang, H.; Cao, G.; Prior, R.L. Total antioxidant capacity of fruits. J. Agric. Food Chem. 1996, 44, 701-705. [CrossRef]

61. Maritim, A.C.; Sanders, R.A.; Watkins, J.B., 3rd. Diabetes, oxidative stress, and antioxidants: A review. J. Biochem. Mol. Toxicol. 2003, 17, 24-38. [CrossRef]

62. Siti, H.N.; Kamisah, Y.; Kamsiah, J. The role of oxidative stress, antioxidants and vascular inflammation in cardiovascular disease (A review). Vascul. Pharmacol. 2015, 71, 40-56. [CrossRef]

63. Gaziano, J.M.; Hennekens, C.H. Vitamin antioxidants and cardiovascular disease. Curr. Opin. Lipidol. 1992, 3, 291-294. [CrossRef]

64. Gale, C.R.; Martyn, C.N.; Winter, P.D.; Cooper, C. Vitamin C and risk of death from stroke and coronary heart disease in cohort of elderly people. BMJ 1995, 310, 1563-1566. [CrossRef]

65. Aune, D.; Keum, N.; Giovannucci, E.; Fadnes, L.T.; Boffetta, P.; Greenwood, D.C.; Tonstad, S.; Vatten, L.J.; Riboli, E.; Norat, T. Dietary intake and blood concentrations of antioxidants and the risk of cardiovascular disease, total cancer, and all-cause mortality: A systematic review and dose-response meta-analysis of prospective studies. Am. J. Clin. Nutr. 2018, 108, 1069-1091. [CrossRef]

66. Pang, K.L.; Chin, K.Y. The role of tocotrienol in protecting against metabolic diseases. Molecules 2019, 24, 923. [CrossRef]

67. Qureshi, A.A.; Peterson, D.M.; Hasler-Rapacz, J.O.; Rapacz, J. Novel tocotrienols of rice bran suppress cholesterogenesis in hereditary hypercholesterolemic swine. J. Nutr. 2001, 131, 223-230. [CrossRef]

68. Minhajuddin, M.; Beg, Z.H.; Iqbal, J. Hypolipidemic and antioxidant properties of tocotrienol rich fraction isolated from rice bran oil in experimentally induced hyperlipidemic rats. Food Chem. Toxicol. 2005, 43, 747-753. [CrossRef]

69. Siddiqui, S.; Rashid, K.M.; Siddiqui, W.A. Comparative hypoglycemic and nephroprotective effects of tocotrienol rich fraction (TRF) from palm oil and rice bran oil against hyperglycemia induced nephropathy in type 1 Diabetic rats. Chem. Biol. Interact. 2010, 188, 651-658. [CrossRef]

70. Siddiqui, S.; Ahsan, H.; Khan, M.R.; Siddiqui, W.A. Protective effects of tocotrienols against lipid-induced nephropathy in experimental type-2 Diabetic rats by modulation in TGF-beta expression. Toxicol. Appl. Pharmacol. 2013, 273, 314-324. [CrossRef]

71. Iqbal, J.; Minhajuddin, M.; Beg, Z.H. Suppression of 7,12-Dimethylbenz[ $\alpha$ ]anthracene-induced carcinogenesis and hypercholesterolaemia in rats by tocotrienol-rich fraction isolated from rice bran oil. Eur. J. Cancer Prev. 2003, 12, 447-453. [CrossRef] 
72. Fukui, K.; Shirai, M.; Ninuma, T.; Kato, Y. Anti-obesity effects of tocotrienols and bran in high-fat diet-treated mice. Nutrients 2019, 11, 830. [CrossRef]

73. Baliarsingh, S.; Beg, Z.H.; Ahmad, J. The therapeutic impacts of tocotrienols in type 2 Diabetic patients with hyperlipidemia. Atherosclerosis 2005, 182, 367-374. [CrossRef]

74. Yang, C.S.; Luo, P.; Zeng, Z.; Wang, H.; Malafa, M.; Suh, N. Vitamin E and cancer prevention: Studies with different forms of tocopherols and tocotrienols. Mol. Carcinog. 2020, 59, 365-389. [CrossRef]

75. Sookwong, P.; Nakagawa, K.; Murata, K.; Kojima, Y.; Miyazawa, T. Quantitation of tocotrienol and tocopherol in various rice brans. J. Agric. Food Chem. 2007, 55, 461-466. [CrossRef]

76. Aggarwal, B.B.; Sundaram, C.; Prasad, S.; Kannappan, R. Tocotrienols, the vitamin E of the 21st century: Its potential against cancer and other chronic diseases. Biochem. Pharmacol. 2010, 80, 1613-1631. [CrossRef]

77. Di Vincenzo, A.; Tana, C.; El Hadi, H.; Pagano, C.; Vettor, R.; Rossato, M. Antioxidant, anti-inflammatory, and metabolic properties of tocopherols and tocotrienols: Clinical implications for vitamin e supplementation in diabetic kidney disease. Int. J. Mol. Sci. 2019, 20, 5101. [CrossRef]

78. Shibata, A.; Kawakami, Y.; Kimura, T.; Miyazawa, T.; Nakagawa, K. Alpha-tocopherol attenuates the triglyceride- and cholesterollowering effects of rice bran tocotrienol in rats fed a western diet. J. Agric. Food Chem. 2016, 64, 5361-5366. [CrossRef]

79. Qureshi, A.A.; Salser, W.A.; Parmar, R.; Emeson, E.E. Novel tocotrienols of rice bran inhibit atherosclerotic lesions in C57BL/6 ApoE-deficient mice. J. Nutr. 2001, 131, 2606-2618. [CrossRef]

80. Kanaya, Y.; Doi, T.; Sasaki, H.; Fujita, A.; Matsuno, S.; Okamoto, K.; Nakano, Y.; Tsujiwaki, S.; Furuta, H.; Nishi, M.; et al. Rice bran extract prevents the elevation of Plasma Peroxylipid in KKAy Diabetic mice. Diabetes Res. Clin. Pract. 2004, 66 (Suppl. S1), S157-S160. [CrossRef]

81. Holscher, H.D. Dietary fiber and prebiotics and the Gastrointestinal Microbiota. Gut Microbes 2017, 8, 172-184. [CrossRef] [PubMed]

82. Jones, J.R.; Lineback, D.M.; Levine, M.J. Dietary reference intakes: Implications for fiber labeling and consumption: A summary of the International Life Sciences Institute North America fiber workshop, 1-2 June 2004, Washington, DC. Nutr. Rev. 2006, 64, 31-38. [CrossRef] [PubMed]

83. Stephen, A.M.; Cummings, J.H. Mechanism of action of dietary fibre in the human colon. Nature 1980, 284, 283-284. [CrossRef] [PubMed]

84. Meyer, K.A.; Kushi, L.H.; Jacobs, D.R., Jr.; Slavin, J.; Sellers, T.A.; Folsom, A.R. Carbohydrates, dietary fiber, and incident type 2 Diabetes in older women. Am. J. Clin. Nutr. 2000, 71, 921-930. [CrossRef]

85. Jenkins, D.J.; Wolever, T.M.; Leeds, A.R.; Gassull, M.A.; Haisman, P.; Dilawari, J.; Goff, D.V.; Metz, G.L.; Alberti, K.G. Dietary fibres, fibre analogues, and glucose tolerance: Importance of viscosity. Br. Med. J. 1978, 1, 1392-1394. [CrossRef]

86. Jesch, E.D.; Carr, T.P. Food ingredients that inhibit cholesterol absorption. Prev. Nutr. Food Sci. 2017, $22,67-80$.

87. Schulze, M.B.; Liu, S.; Rimm, E.B.; Manson, J.E.; Willett, W.C.; Hu, F.B. Glycemic index, glycemic load, and dietary fiber intake and incidence of type 2 Diabetes in younger and middle-aged women. Am. J. Clin. Nutr. 2004, 80, 348-356. [CrossRef]

88. Tessari, P.; Lante, A. A Multifunctional bread rich in beta glucans and low in starch improves metabolic control in type 2 Diabetes: A controlled trial. Nutrients 2017, 9, 297. [CrossRef]

89. Yao, B.; Fang, H.; Xu, W.; Yan, Y.; Xu, H.; Liu, Y.; Mo, M.; Zhang, H.; Zhao, Y. Dietary fiber intake and risk of type 2 Diabetes: A dose-response analysis of prospective studies. Eur. J. Epidemiol. 2014, 29, 79-88. [CrossRef]

90. US Food and Drug Administration. Food labeling: Health claims; oats and coronary heart disease. Final rule. Fed. Regist 1997, 62, 3583-3601.

91. Bell, S.; Goldman, V.M.; Bistrian, B.R.; Arnold, A.H.; Ostroff, G.; Forse, R.A. Effect of beta-glucan from oats and yeast on serum lipids. Crit. Rev. Food Sci. Nutr. 1999, 39, 189-202. [CrossRef]

92. Biörklund, M.; van Rees, A.; Mensink, R.P.; Onning, G. Changes in serum lipids and postprandial glucose and insulin concentrations after consumption of beverages with beta-glucans from oats or barley: A randomised dose-controlled trial. Eur. J. Clin. Nutr. 2005, 59, 1272-1281. [CrossRef]

93. Braaten, J.T.; Wood, P.J.; Scott, F.W.; Wolynetz, M.S.; Lowe, M.K.; Bradley-White, P.; Collins, M.W. Oat beta-glucan reduces blood cholesterol concentration in hypercholesterolemic subjects. Eur. J. Clin. Nutr. 1994, 48, 465-474.

94. Theuwissen, E.; Mensink, R.P. Simultaneous intake of beta-glucan and plant stanol esters affects lipid metabolism in slightly hypercholesterolemic subjects. J. Nutr. 2007, 137, 583-588. [CrossRef]

95. Dong, J.; Cai, F.; Shen, R.; Liu, Y. Hypoglycaemic effects and inhibitory effect on intestinal disaccharidases of oat beta-glucan in streptozotocin-induced diabetic mice. Food Chem. 2011, 129, 1066-1071. [CrossRef]

96. Zhang, P.P.; Hu, X.Z.; Zhen, H.M.; Xu, C.; Fan, M.T. Oat beta-glucan increased atpases activity and energy charge in small intestine of rats. J. Agric. Food Chem. 2012, 60, 9822-9827. [CrossRef]

97. Maki, K.C.; Galant, R.; Samuel, P.; Tesser, J.; Witchger, M.S.; Ribaya-Mercado, J.D.; Blumberg, J.B.; Geohas, J. Effects of consuming foods containing oat beta-glucan on blood pressure, carbohydrate metabolism and biomarkers of oxidative stress in men and women with elevated blood pressure. Eur. J. Clin. Nutr. 2007, 61, 786-795. [CrossRef]

98. Mäkeläinen, H.; Anttila, H.; Sihvonen, J.; Hietanen, R.M.; Tahvonen, R.; Salminen, E.; Mikola, M.; Sontag-Strohm, T. The effect of beta-glucan on the glycemic and insulin index. Eur. J. Clin. Nutr. 2007, 61, 779-785. [CrossRef] 
99. Guo, H.; Ding, J.; Liang, J.; Zhang, Y. Associations of whole grain and refined grain consumption with metabolic syndrome. A meta-analysis of observational studies. Front. Nutr. 2021, 8, 695620. [CrossRef]

100. Vitale, M.; Hanhineva, K.; Koistinen, V.; Auriola, S.; Paananen, J.; Costabile, G.; Della Pepa, G.; Rivellese, A.A.; Riccardi, G.; Giacco, R. Putative metabolites involved in the beneficial effects of wholegrain cereal: Nontargeted metabolite profiling approach. Nutr. Metab. Cardiovasc. Dis. 2021, 31, 1156-1165. [CrossRef]

101. Kristensen, M.; Bügel, S. A Diet rich in oat bran improves blood lipids and hemostatic factors and reduces apparent energy digestibility in young healthy volunteers. Eur. J. Clin. Nutr. 2011, 65, 1053-1058. [CrossRef] [PubMed]

102. Qiu, J.; Liu, Y.; Yue, Y.; Qin, Y.; Li, Z. Dietary tartary buckwheat intake attenuates insulin resistance and improves lipid profiles in patients with type 2 Diabetes: A randomized controlled trial. Nutr. Res. 2016, 36, 1392-1401. [CrossRef] [PubMed]

103. Vitaglione, P.; Mennella, I.; Ferracane, R.; Rivellese, A.A.; Giacco, R.; Ercolini, D.; Gibbons, S.M.; La Storia, A.; Gilbert, J.A.; Jonnalagadda, S.; et al. Whole-grain wheat consumption reduces inflammation in a randomized controlled trial on overweight and obese subjects with unhealthy dietary and lifestyle behaviors: Role of polyphenols bound to cereal dietary fiber. Am. J. Clin. Nutr. 2015, 101, 251-261. [CrossRef] [PubMed] 